\title{
A critical review on the theoretical framework of differential motor learning and meta-analytic review on the empirical evidence of differential motor learning
}

\author{
Ben Serrien ${ }^{1}$, Bruno Tassignon ${ }^{1}$, Jean-Pierre Baeyens ${ }^{1,2,3}$ \& Ron Clijsen ${ }^{1,2,4}$ \\ ${ }^{1}$ Vrije Universiteit Brussel, Faculty of Physical Education and Physiotherapy (Brussels, Belgium) \\ ${ }^{2}$ Thim Van Der Laan University College Physiotherapy (Landquart, Switzerland) \\ ${ }^{3}$ Universiteit Antwerpen, Faculty of Applied Engineering (Antwerp, Belgium) \\ ${ }^{4}$ Scuola Universitaria Professionale della Svizzera Italiana
}

Corresponding author:

Ben Serrien

ben.serrien@vub.be

Vrije Universiteit Brussel - Faculty of Physical Education and Physiotherapy

Pleinlaan 2

1050 Brussels - Belgium

article submitted to Human Movement Science 


\begin{abstract}
Objective. Differential learning is a motor learning method characterized by a high amount of variability during practice. The objective of this paper is twofold. First, a critical appraisal is performed of the theoretical rationale of the differential learning method. Second, a systematic review and meta-analysis of experimental results is made to compare the effectiveness of differential learning compared to other motor learning methods.

Methods. Narrative review of the theoretical rationale of differential learning. Systematic review and meta-analysis of published randomized controlled trials where differential learning is compared to other motor learning methodologies.

Results. The theoretical rationale of differential learning is reasonable, but at some points too metaphorically formulated. Especially the use of stochastic resonance as the mechanism behind differential learning is ambiguous and remains untested to this day. However, indirect evidence for a neurophysiological mechanism has been described and should be pursued further. Empirically, differential learning has been examined in a variety of contexts ranging from technical skills and performance outcomes in single sports movements to tactical sports contexts, fine motor skills, balance tasks and rehabilitation. The meta-analysis showed that differential learning performed better than traditional motor learning methods and that the effect was larger on the retention test than on the post-test. However, little to no evidence was found for the comparison to other variability-based motor learning techniques. Additionally, risk of bias was high or unclear on many items and publication bias was likely which limits strong confidence in the conclusions of the meta-analysis.
\end{abstract}

Perspectives. Differential learning is a promising method to enhance motor learning but will require further research to test certain theoretical claims and to find factors that predict the individual and time-dependent optimal amount of practice variability.

Keywords: motor learning; variability; differential learning; sports; contextual interference; meta-analysis 


\section{Introduction}

How the process of acquiring and learning new motor skills can be enhanced is one of the basic questions in theoretical and applied movement science, rehabilitation and sport. It is twenty years ago since the differential learning (DL) approach was proposed by prof. Wolfgang Schöllhorn (Schöllhorn, 1999) as an enhanced motor learning strategy. Since then, several studies have experimentally tested this approach in various settings. The initial experiments were mainly oriented towards performance in a single movement (sports context), but recently it has been adopted by tactical sports contexts and clinical settings as well. The approach is not undebated however (Hossner, Käch, \& Enz, 2016a, 2016b, Künzell \& Hossner, 2012, 2013; Schöllhorn, 2016) and requires further examination on several claims and predictions. On the website dls-sports.com, the following features are ascribed to DL: “(1) DL initiates most effective learning leading to highest performance with fun; (2) DL prevents sports injuries in a most effective way; (3) DL does not only affect your body but also your brain in a holistic way; (4) DL is based on most recent scientific findings; (5) DL will not only improve your performance, it will change your personality; and (6) DL was the basis for many other upcoming training and technique concepts". This list of amazing features warrants healthy skepticism towards DL given that the current state of literature does not support some of the topics included in these statements.

In section 2, we present a critical appraisal the theoretical rationale of the DL approach and its contrast with other motor learning paradigms. In section 3, we present a systematic review and meta-analysis of the experimental evidence that compares DL to other motor learning paradigms. The last section will present an overall discussion and avenues for further research. 


\section{Theoretical rationale of differential learning}

2.1. Etymology and definition. The term differential learning is derived from the differences or differential changes in movement patterns that provide additional information for the movement system from which it can learn (Schöllhorn, 2016; Schöllhorn, Michelbrink, Welminsiki, \& Davids, 2009). The differential aspect of the learning method comes from the high variability in movement executions, and even the performance of apparent erroneous movements. This is highlighted in the DL motto: "never train in the 'right way' in order to become the best" (Schöllhorn, Beckmann, \& Davids, 2010). The inspiration for the crucial role of variability in learning comes from principles of selforganization and dynamical systems theory (Frank, Michelbrink, Beckmann, \& Schöllhorn, 2008; Kelso, 1995; Schöllhorn, 2000; Zanone \& Kelso, 1992). Because literature does not present a precise definition of DL, we enumerate here a number of statements from literature ter illustration:

1. "DL [...] realizes movement variability by adding stochastic perturbations to a central movement pattern in order to ensure no precise movement repetitions and no corrections during the skill acquisition process." (Schöllhorn, Hegen, \& Davids, 2012). "The learner is confronted with a variety of exercises that extend the whole range of possible solutions for a specific task" (Savelsbergh, Kamper, Rabius, De Koning, \& Schöllhorn, 2010). "[...] with the intention to provide a larger space of solutions to the athlete, where $\mathrm{s} / \mathrm{he}$ can react more individually and more specifically in a shorter time" (Schöllhorn, Beckmann, Janssen, \& Drepper, 2010).

2. "[...] systematic indications for proceeding in DL in technique and strength training could be: variation of initial and final conditions of a movement, change of variables range, changing of a movements time course with respect to relative and absolute duration and rhythm. [...] possibilities of variation can be applied to every joint to following parameters: joint angle, velocity, acceleration. In combination with the exclusion of certain extremities during a movement or in combination with changing internal boundary conditions like muscular fatigue or psychological states of arousiness the amount of differentiation possibilities becomes enormous" (Schöllhorn, 2000).

3. "An important idea in DL is the enlargement of differences between subsequent movements [...]" (Schöllhorn, Michelbrink, et al., 2009). " [...] every exercise was combined with a new instruction that was always related to the previous exercise, but with an additional task" (Schöllhorn, Beckmann, Janssen, et al., 2010).

4. "Blurred, "erroneous" variants of a single task were executed and no variant was instructed twice. In the extreme, the test movement was never executed during the acquisition process" (Schöllhorn, 2016). In cases of an 'incorrect' execution (of the variant), the task was repeated 
up to a maximum of three times until the actual performance matched the demands" (Hossner et al., 2016b).

5. "Differential training consisted of [...] no corrective instructions" (Schöllhorn et al., 2006). "The participants did not receive any feedback about their performance" (Savelsbergh et al., 2010).

A video with some examples of DL-exercises for shot put training can be found online (Valentiner, 2007). An attempt towards a definition of DL may be the following:

"Differential learning employs movement variability in an attempt to enhance performance. Nearly all forms of variation on a given movement are allowed. Movement variability is induced primarily by instructions describing specific variations of how a certain segment/joint/limb (or sets of joints/segments/limbs) should behave during the movement (position, angle, velocity, acceleration, rhythm, sequence, ...). Other sources of variability can include changes in internal and external boundary conditions (dual tasks, fatigue, mental state, environment, equipment, opponents, ...). Each movement variation is only repeated once or two/three times at most. The differences between subsequent movement variations can be large (chaotic DL) or small (gradual DL or structural learning)."

2.2. Contrast with other motor learning methods. The former statements and definition highlight that DL involves variability in movement execution, but it should be noted that it is different from other methods who employ variability to some extent. Traditional learning (TL) approaches require the execution of a movement in a specified 'optimal' prototype manner and include repetitive practice (REP) and methodological series of exercises (MSE) as ways to achieve this. The former includes variability in the sense that biological movement systems have zero chance of performing a movement two times the same way because of the abundant degrees-of-freedom available to them (Bernstein, 1967; Hatze, 1986). The latter adds variability in the sense that specific exercises are given to the learner that show increasing similarity to the prototype movement; the series are sequentially performed from easy to difficult and from simple to complex. Both approaches require a large number of repetitions to learn. More variability is introduced in the variable practice (VP) approach, based on the notion of generalized motor programs (Schmidt, 1975). The prototype movement pattern is assumed to be part of a class of similar movements that share invariant 
features (relative timing of joint motions, relative force distributions, ...) and has variant features specific to the motion itself. The VP approach requires that all practice exercises share the same invariant features of the prototype pattern, but that they all present differences in the variant features in order to cover a wide space of variable patterns around the central pattern. In the contextual interference $(\mathrm{CI})$ approach, practice variability is increased by practicing one or more additional movements in conjunction with the target movement in either blocked (low CI) or random (high CI) sequences. Low CI is generally associated with enhanced acquisition rates, but impaired learning rates at retention tests whereas the opposite is true for high CI (Brady, 2004).

DL distinguishes itself from the former in the sense that its rationale is based on the rebuttal of two implicit assumptions in other approaches, namely (1) the to-be-learned optimal prototype movement is considered independent of individual and time; and (2) the movement performance can be improved by repetitions of (invariant parts of) the movement (Schöllhorn, Beckmann, \& Davids, 2010). In contrast to REP and MSE, DL attempts to let performers find their individual- and time specific optimal motion patterns which may encourage the finding of new creative solutions (Orth, van der Kamp, Memmert, \& Savelsbergh, 2017) instead of optimizing a putative prototype pattern. The abstinence of feedback and corrective instructions to augment learning in most DL experiments can be explained by the rebuttal of these assumptions. Schöllhorn (2016) acknowledged that the lack of feedback is more a byproduct than part of the DL method. Hossner et al. (2016b) showed that adding feedback and corrective instructions to basic DL does not produce marked differences. The importance of movement variability is also recognized in other motor learning models which - in contrast to DL - explicitly rely on feedback, error-corrections and repetition of favorable outcomes (Barbado, Caballero, Moreside, Vera-Garcia, \& Moreno, 
2017; Caballero et al., 2017; Dhawale, Smith, \& Ölveczky, 2017; Ranganathan \& Newell, 2013; Wu, Miyamoto, Castro, Ölveczky, \& Smith, 2014).

Whereas VP requires the practice exercises to share the same invariants as the target movement, DL does not so by inducing variations in all possible motion parameters. In CI, two to four different movements are practiced together, whereas DL focuses on one movement and attempts to make as much as possible variations around this movement. However, attempts have been made to use DL for practicing two different movements simultaneously too (Schöllhorn et al., 2012). DL is clearly different from VP and CI, but Hossner et al. pointed out that an advantage of DL over these methods could be counted as evidence for their respective underlying theories as well (schema theory and elaborative processing), because DL exercises inevitably provide a context to the task and both variant and invariant aspects of the task are manipulated in DL (Hossner et al., 2016b).

A more difficult distinction is between subtypes of DL (chaotic and gradual) and structural learning (SL). It is not our intention to reopen here the discussion that followed the article of Hossner et al. (2016b), which resolved (among other things) around whether DL advocates the maximization of differences between consecutive exercises and the effects thereof on learning. The first statement in the third set above (section 2.1) seems to advocate a maximization (see also translations of similar statement in Hossner et al., 2016b), whereas the second statement is more in line with SL where the subsequent movements differ, but in a limited way. However, both maximization and minimization per se seem at odds with the individuality - and hence finding optimal levels for each individual - which the DL approach adheres (Schöllhorn, 1999). To conclude, both gradual and chaotic DL and SL advocate for a large overall inter-trial variability, but gradual DL and SL (whether they are the same or not) advocate that this should be accomplished in a way as to minimize sequential inter-trial 
variability which would allow subjects to identify the structure of their coordination potential (see Figure 1 in Hossner et al. (2016b) for a metaphorical interpretation).

Another difficult distinction is with nonlinear pedagogy in the constraints-led approach (CLA). This method tries to identify key constraints in the learner-environment-task space (with an emphasis on task constraints) and manipulates these in order to facilitate motor learning (Button, Lee, Mazumder, Tan, \& Chow, 2012; Renshaw, Chow, Davids, \& Button, 2015). In contrast, DL does not identify key task constraints because it seems hard to identify key constraints that are valid for each individual and situation (Schöllhorn et al., 2012). Although CLA is based on ecological dynamics and DL on dynamical systems theory, the difference between the two seems more pragmatic than theoretical. As quoted in the second set of statements above, DL also uses the environment and equipment as constraints to induce fluctuations like the CLA does, but DL seems to focus primarily on explicit instructions on how to perform an exercise, whereas CLA tends more to the implicit part of the spectrum of motor learning (Davids, Araújo, Shuttleworth, \& Button, 2003).

2.3. Biomechanics and motor control. The major rationale for DL seems to come from the phenomenon of inter- and intra-individual movement variability. Given the increasing abundance in degrees-of-freedom at mechanical, muscular and neural levels and several potential perturbations (Hatze, 1986; Turvey, 1990), each execution of a given movement will be different in some respect. Moreover, individual differences in anatomical, physiological, biomechanical and neural parameters influence the intrinsic coordination dynamics and affect the learning rate. The motion patterns that subjects use change intrinsically and involves both stochastic and deterministic components on several time scales (Schöllhorn, Mayer-Kress, Newell, \& Michelbrink, 2009). Based on these evidences, the rationale is then formulated as: "If movement repetitions are never identical and even after thousands repetitions deviations 
can be diagnosed, then it is reasonable to consider an approach that prepares the individual for the novel aspects of a movement repetition that will occur anyway. Furthermore, the time independence of the chosen ideal movement template is not valid" (Schöllhorn, Beckmann, \& Davids, 2010). We agree with the reasoning that a variable training program is closer to the reality of repeating without repetition (Bernstein, 1967) and that subjects should experience perturbations to their motion patterns which may prepare them for unexpected situations. We also agree with a time- and individual dependent optimal movement pattern. However, DL, as it is implemented thus far in experiments, instructs subjects to perform a movement in a new specific way which allows planning the movement and thus no real unprepared situation occurs during the acquisition phase (no real time pressure). Furthermore, the experimental testing generally aims on subjects performing as best as they can in a basic unperturbed context and thus not on testing how well they perform in novel unexpected situations (exceptions are the studies on tactical behaviour: Coutinho et al., 2018; Santos et al., 2018). It thus seems that the DL method is not in direct accord with its rationale as cited above, but is primarily aimed at performance. Recent recommendations in motor learning for rehabilitation and prevention of secondary injuries have suggested DL as part of the training schedule to prepare the athlete better for unexpected situations (Gokeler, Neuhaus, Benjaminse, Grooms, \& Baumeister, 2019). The rationale for using DL in this respect is sound, but has not been experimentally tested to our knowledge.

2.4. Stochastic resonance. Stochastic resonance (SR) is often quoted as the theoretical mechanism responsible for the beneficial effects of differential learning (Schöllhorn et al., 2006; Schöllhorn, Mayer-Kress, et al., 2009; Schöllhorn, Michelbrink, et al., 2009), but this serves only as a metaphor and has never been quantified thus far. SR in the original physical meaning is adding a specific amount of white noise (containing all frequencies) to a certain 
signal whereby the signal will resonate (amplification) with the parts of the noise that contain the same frequencies as the signal. Statements can be found in the DL literature that correspond to two different interpretations of how SR is understood. In the classical interpretation, the resonance occurs between two signals, one signal being the noisy dynamic condition of the athlete (intrinsic dynamic changes in performance and motion pattern) and the second signal the noisy changes in the continuously different exercises (Schöllhorn, Mayer-Kress, et al., 2009; Schöllhorn, Michelbrink, et al., 2009). In this classic interpretation, the resonance occurs at a certain optimal amount of noise in the signal under control, i.e. in the second signal. A sharp peak in learning rate is hypothesized in the range close to this optimal amount. The continuum of motor learning methods with increasing variability (REP $<\mathrm{MSE}<\mathrm{VP}<\mathrm{CI}<\mathrm{SL}<\mathrm{DL}$ ), combined with free practice regimes, was presented by Schöllhorn, Mayer-Kress, et al. (2009) to lie on an inverted U-shape. Based on the assumption of higher learning rates in DL compared to these other methods, DL was set at the top of the model, reflecting the implicit assumption that DL lies at the peak of the resonance curve. We agree that the discussed motor learning methods are part of a continuum, but based on the strong emphasis on individuality and time-dependence by Schöllhorn et al. (which we also agree with), we fail to see why this continuum should invariantly show SR (optimal learning rate) at DL. In other places, frequent reference is given to 'optimal amounts of noise' which should imply variable locations of the peak, which may be outside the DL regime. Besides a possible variable/dynamic location of the resonance curve, more problematic is that SR is not defined exactly in DL literature and remains untested (Schöllhorn, Mayer-Kress, et al., 2009). Also the dynamical-systems model of DL by Frank et al. (2008) could not explain SR. Given these problems, it cannot be used as theoretical justification of the application of DL and to unify all motor learning methods under the umbrella of noise (Schöllhorn et al., 2006). 
A second way that SR is used puts less emphasis on the amount of noise and does not actually imply a true optimum amount. "With an increasing number of offered exercises the probability increases of having one exercise for every group member where s/he will respond to in an adequate way" (Schöllhorn, 2000). "By confronting athletes with a high number of practice activities, the probability increases that any of the training exercises can get in resonance with the athlete's needs" (Schöllhorn et al., 2006). Here, the rationale is for DL exercises to cover a maximal range (or plausible range) of motions patterns, in order to maximize the chance that they get in resonance with the individual and time-dependent optimum, i.e. that the subject discovers something in the executions that is beneficial for his/her specific constraints at that point in time. This does not necessarily imply large differences from one exercise to the next, but an overall wide range of variability within each training session (cfr. the debate between SL and gradual DL). In this respect, the metaphor of a perceptual-motor landscape is quoted sometimes; this landscape is constrained by genetic endowment, developmental status, organismic constraints, past learning experiences, intentions and the task requirements (Button et al., 2012). The large amount of variation challenges the movement system into finding new optimal solutions (attractors). Nonequilibrium phase transitions (switching between different stable movement patterns) are indeed facilitated by fluctuations (Beek, 2011; Zanone \& Kelso, 1992). The large variety of DL exercises is used to probe the landscape to find the attractors or "exercises that get in resonance with the athlete's need'.

2.5. Neurophysiology. Although there is no evidence in favor of SR as the theoretical mechanism of DL, analyses of brain activity patterns after DL training sessions provide indirect evidence for a neurophysiological mechanism. In two experiments, Henz et al. examined spontaneous EEG activity in rest before and after badminton training sessions 
based on DL (gradual and chaotic), CI and REP. In the first experiment, DL showed increased frontal theta activity and increased alpha activity in the contralateral parieto-occipital regions, whereas REP showed no differences in theta and alpha activities with respect to pre-training (Henz \& Schöllhorn, 2016). In the second experiment, gradual and chaotic DL showed increased alpha and theta activity in somatosensory regions compared to CI and REP; chaotic-DL distinguished itself from gradual-DL and CI in higher post-training alpha and theta EEG over the motor cortex; and CI and REP showed respectively increases in beta plus gamma EEG in frontal regions and alpha activity in occipital regions (Henz, John, Merz, \& Schöllhorn, 2018). Henz et al. acknowledged the fact that effects of learning on spontaneous EEG are not well understood and cautiously interpret the findings as traces of learning and use-dependent plasticity (long-term potentiation for memory consolidation). Because DL demands subjects to perform a movement in various ways, this increases stimulation of the somatosensory and motor cortex and leaves traces in the post-task EEG patterns. A lack of increase in REP was explained by habituation of the cognitive and motor systems. CI increased higher activity in frontal regions, related to executive cognitive control processes. These results are in line with a recent review that compared brain activity between random and more repetitive practice schedules (Lage et al., 2015). However, in both experiments, no effect on performance was measured so it was unclear whether the training had the intended effect.

Because the amount of dopamine produced in the striatum during acquisition is generally related to the learning rate, and its production is increased with events that surprise with respect to expectations (Schultz, Dayan, \& Montague, 1997), DL proposes that the surprising events due to the blurred movement variants support learning and will lead to most discriminable cortex areas with greater levels of excitation (Schöllhorn, Beckmann, \& 
Davids, 2010). DL exercises can also aid in raising the fun of practicing (also associated with increased dopamine production) and hence the motivation of subjects which will generally enhance learning. Faster learning through increased motivation and dopamine production are also part of the predictions of the OPTIMAL theory by Wulf \& Lewthwaite (2016) (optimizing performance through intrinsic motivation and attention for learning). On the other hand, OPTIMAL theory predicts that enhanced expectancies and an external focus of attention are beneficial for motor learning, whereas DL often uses exercises that have lower expectancies of results and lower performance during training and the instructions of the exercises necessarily put the focus of attention internally because the variations are often expressed in a way as to put the joints in a specific position or perform a certain rhythm. Future studies may compare DL in its current form with DL exercises that are induced through an external focus of attention to examine the compatibility with OPTIMAL theory. 


\section{DL vs. other motor learning methods: systematic review and meta-analysis}

The systematic review and meta-analysis in this section aims to give an objective contribution to the ongoing discussion about the benefits of the differential motor learning approach as compared to other approaches. The PRISMA statement (Shamseer et al., 2015) was followed in drafting this section.

\subsection{Methodology}

Objective (PICOS). The objective of this SRMA is to examine the evidence of randomized controlled studies (S) that compared the effectiveness of differential learning (I) to other motor learning approaches (C: REP, MSE, VP, CI, CLA, SL) in the performance of movement tasks $(\mathrm{O})$ in humans $(\mathrm{P})$.

Eligibility criteria. According to the PICOS terms, the studies that were included had to be randomized experiments with humans where the differentially trained group was compared to a control group that was engaged in a different motor learning regime (lack of practice for the control group was not eligible). The study had to describe the effects on one or more measures of performance in a movement task. No specific criteria were specified for the population. The study report had to be published as a full paper in a journal or as a book chapter (no congress abstracts) to be able to make a reliable risk-of-bias assessment. No restrictions were applied to language or year of publication.

Search process. We searched for articles in PubMed, Web of Science and Google Scholar. The following search string was used in PubMed: (((differential-learning) OR differentialtraining) OR differencial-learning) OR differencial-training[all]. The last search was carried out on $07 / 02 / 2019$. Additional searches were done based on the reference lists of included articles and reviews and on the ResearchGate profiles of authors of included articles. 
Screening procedure. After removal of duplicates, titles and abstracts were screened, followed by an inspection of the full text. All full texts were screened by two authors (BS, BT) and the following information was extracted: first author, year of publication, description of participants (number, age, gender, other characteristics), description of the movement task and the performance variable, description of the training intervention of the DL and other groups (context of the intervention, duration, frequency, number of exercises, number of repetitions, description of the exercises).

Risk of bias assessment. Each study was assessed on 8 sources of bias: selection, performance, detection, attrition, reporting, and other reasons of bias (Moher, Liberati, Tetzlaff, \& Altman, 2009). This was done independently by two authors (BS, BT) and discrepancies were resolved through discussion.

Calculation of effect sizes. The majority of studies were pre-post-test control designs and reported on the effects of differential learning on continuous performance variables. The effect size of choice was therefore a standardized mean difference (Morris, 2008):

$$
d=\frac{c \times\left[\left(M_{\text {post }, D L}-M_{\text {pre }, D L}\right)-\left(M_{\text {post }, C}-M_{\text {pre }, C}\right)\right]}{S D_{\text {pre }}}, \text { where } c \text { represents a correction factor }
$$
for small sample sizes (close to 1 for large samples), $M$ are means, $S D_{\text {pre }}$ is the pooled standard deviation at the pre-test, $C$ is the control group (other motor learning method). The same effect size was used for the retention test (retention - pre). When a study reported more than one retention test, the latest test was used in our analysis. Results on transfer tests to other than the target movement were not included because there were too few studies on transfer effects. In studies that provided no means and SDs, but the individual change scores

$(\delta)$ were given, the effect size was calculated as $\quad d=\frac{c \times\left(M_{\delta, D L}-M_{\delta, C}\right)}{S D_{\delta, \text { pooled }}}$. To estimate the 
standard error of $d$, we needed the pre-post correlation, but this was not included in any report. For the primary analysis, we took $r=0.50$ as a reasonable mean estimate. Sensitivity analyses were performed with $r=0.15$ and 0.85 to examine the influence of this parameter on the overall results of the meta-analysis. The study of Pabel, Pabel, Schmickler, Schulz, \& Wiegand (2017) used a discrete measure (fail or pass on an exam). The log odds ratio was calculated for the data presented in this study and then converted to a standardized mean difference with the formulas presented in Borenstein, Hedges, Higgins, \& Rothstein (2009) (chapters 5 and 7). Similar for the study of Pabel, Freitag, Hrasky, Zapf, \& Wiegand (2018) who reported log odds ratios. For studies that reported multiple outcome variables, we calculated the weighted average effect size. When a study did not report all outcomes, authors were contacted by email. When authors did not respond, but the article contained figures with enough information to calculate the effect size, a software program (GetData-GraphDigitizer.com) was used to extract the raw study data.

Meta-analyses. Separate meta-analyses for the effects of acquisition (pre vs. post) and learning (pre vs. retention) were carried out. In each meta-analysis, subgroup analyses were performed based on the type of task and type of contrasted learning method. All metaanalyses were carried out in Review Manager 5.3 (Cochrane Collaboration). Studies that used different subgroups (e.g. based on age) were entered separately in the meta-analysis. Random effects models were used throughout as between-study variation was expected based on the heterogeneity of movement tasks, subject characteristics, study designs and performance variables (Borenstein et al., 2009). The inverse of the variance was used to weigh each study result on the overall mean and $95 \%$ CI. Heterogeneity was reported as $I^{2}$. Publication bias was visually inspected with a funnel plot. Supplementary material may be found online at https://osf.io/m4sje/. 


\subsection{Results}

3.2.1. Qualitative synthesis and risk of bias. The flowchart in Figure 1 shows the results of the search and screening process and the numbers of articles included in the qualitative $(n=$ $20)$ and quantitative $(n=16)$ synthesis. The features of the included articles are described in Table 1.

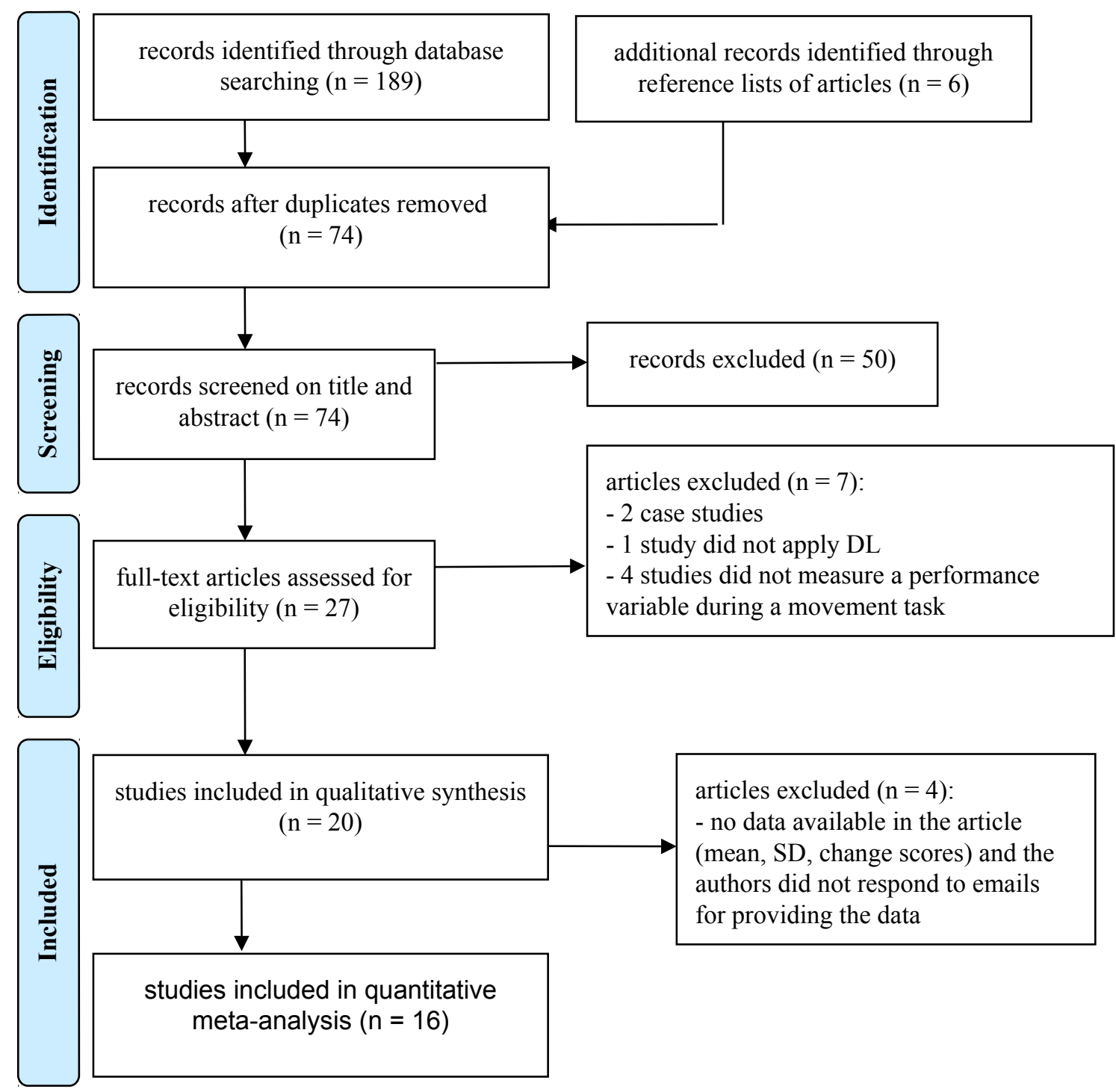

Figure 1: Flowchart of the search and screening process (based on the PRISMA statement template). 
Table 1. Design, participants, movement tasks, performance variables and training interventions of studies included in the qualitative synthesis.

\begin{tabular}{|c|c|c|c|c|c|c|c|}
\hline $\begin{array}{l}\text { First author, } \\
\text { year, design }\end{array}$ & Participants & Context & Movement task & $\begin{array}{l}\text { Performance } \\
\text { variable }\end{array}$ & $\begin{array}{l}\text { Duration, } \\
\text { frequency }\end{array}$ & Differential Learning & Other training \\
\hline $\begin{array}{l}\text { Schöllhorn, } \\
2004 \text { (exp. 1) } \\
\text { PPC: } \\
\text { DL vs. TL }\end{array}$ & $\begin{array}{l}\text { Trained soccer players }(\mathrm{M}) \\
\text { in the German regional } \\
\text { league } \\
\text { (age } 21.9 \pm 3.7 \text { ) } \\
\text { DL: } \mathrm{n}=10 \\
\text { TL: } \mathrm{n}=10\end{array}$ & $\begin{array}{l}\text { Supplemental } \\
\text { to normal } \\
\text { club training }\end{array}$ & $\begin{array}{l}\text { Soccer: goal } \\
\text { shooting (sports } \\
\text { technical skills) }\end{array}$ & $\begin{array}{l}\text { Points scored over } \\
35 \text { trials divided } \\
\text { over } 4 \text { initial ball } \\
\text { locations (optimal } \\
\text { target locations } \\
\text { recieved more } \\
\text { points) }\end{array}$ & $\begin{array}{l}6 \text { weeks } \\
2 \text { sessions week }^{-1} \\
(25 \mathrm{~min})\end{array}$ & $\begin{array}{l}\text { nr. of exercises: ? } \\
\text { nr. of repetitions: } 1 \\
\text { exercises described: no, } \\
\text { only sources of } \\
\text { variation } \\
\text { feedback: no }\end{array}$ & $\begin{array}{l}\text { TL: REP } \\
\text { nr. of repetitions: ? } \\
\text { reference of optimal } \\
\text { motion: yes } \\
\text { feedback: yes, corrective } \\
\text { instructions }\end{array}$ \\
\hline $\begin{array}{l}\text { Schöllhorn, } \\
2004 \text { (exp. 2) } \\
\text { PPC: } \\
\text { DL vs. TL }\end{array}$ & $\begin{array}{l}\text { Trained soccer players }(M) \\
\text { from a senior (age } 23.5 \pm \\
3.8) \text { and a junior }(12.1 \pm \\
\text { 1.7) soccer team. } \\
\text { DL: } \mathrm{n}=8 \text { senior }+14 \text { junior } \\
\text { TL: } \mathrm{n}=8 \text { senior }+13 \text { junior }\end{array}$ & $\begin{array}{l}\text { Supplemental } \\
\text { to normal } \\
\text { club training }\end{array}$ & $\begin{array}{l}\text { Soccer: } \\
\text { dribbling and } \\
\text { passing }\end{array}$ & $\begin{array}{l}\text { Passing the ball } \\
\text { towards a target at } \\
20 \mathrm{~m} \text { in front of the } \\
\text { subjects. Straight } \\
\text { pass } 6 \text { points, less } \\
\text { points for deviations } \\
\text { to the left and right. } \\
\text { Task was performed } \\
5 \text { times. }\end{array}$ & $\begin{array}{l}4 \text { weeks } \\
3 \text { sessions week }{ }^{-1} \\
(20-40 \mathrm{~min})\end{array}$ & $\begin{array}{l}\text { nr. of exercises: ? } \\
\text { nr. of repetitions: } 1 \\
\text { exercises described: no } \\
\text { feedback: no }\end{array}$ & $\begin{array}{l}\text { TL: REP } \\
\text { nr. of repetitions: ? } \\
\text { reference of optimal } \\
\text { motion: yes } \\
\text { feedback: yes, corrective } \\
\text { instructions }\end{array}$ \\
\hline $\begin{array}{l}\text { Schöllhorn, } \\
2004 \text { (exp. 3) } \\
\text { PPC: } \\
\text { DL vs. TL }\end{array}$ & $\begin{array}{l}\text { Soccer players from the } \\
\text { German provincial and } \\
\text { regional leagues. } \\
\text { DL: } \mathrm{n}=12 \text { (mean age } 23.8 \text { ) } \\
\text { TL: } \mathrm{n}=13 \text { (mean age } 28.1 \text { ) }\end{array}$ & $\begin{array}{l}\text { Supplemental } \\
\text { to normal } \\
\text { club training }\end{array}$ & $\begin{array}{l}\text { Soccer: ball } \\
\text { reception test }\end{array}$ & $\begin{array}{l}\text { Distance between } \\
\text { initial ball contact } \\
\text { and the position of } \\
\text { the ball after control } \\
\text { when receiving the } \\
\text { ball. }\end{array}$ & $\begin{array}{l}4 \text { weeks } \\
7 \text { sessions of } 15- \\
20 \text { min }\end{array}$ & $\begin{array}{l}\text { nr. of exercises: } 18-24 \\
\text { per session } \\
\text { nr. of repetitions: } 1 \\
\text { exercises described: no } \\
\text { feedback:? }\end{array}$ & $\begin{array}{l}\text { TL: REP } \\
\text { nr. of repetitions: ? } \\
\text { reference of optimal } \\
\text { motion: yes } \\
\text { feedback: yes, corrective } \\
\text { instructions }\end{array}$ \\
\hline $\begin{array}{l}\text { Schöllhorn, } \\
2006 \text { (exp. 1) } \\
\text { PPC: } \\
\text { DL vs TL }\end{array}$ & $\begin{array}{l}\text { Senior soccer team } 5^{\text {th }} \\
\text { German division }(\mathrm{M}) \text {. } \\
\text { Allocation based on pre-test } \\
\text { scores. } \\
\text { DL: } \mathrm{n}=8 \\
\text { TL: } \mathrm{n}=8\end{array}$ & $\begin{array}{l}\text { Supplemental } \\
\text { to normal } \\
\text { club training }\end{array}$ & $\begin{array}{l}\text { Soccer: } \\
\text { dribbling and } \\
\text { passing }\end{array}$ & $\begin{array}{l}\text { Passing the ball } \\
\text { towards a target at } \\
20 \mathrm{~m} \text { in front of the } \\
\text { subjects. Straight } \\
\text { pass } 6 \text { points, less } \\
\text { points for deviations } \\
\text { to the left and right. } \\
\text { Task was performed } \\
5 \text { times. }\end{array}$ & $\begin{array}{l}4 \text { weeks } \\
3 \text { sessions week }{ }^{-1} \\
(20-40 \mathrm{~min})\end{array}$ & $\begin{array}{l}\text { nr. of exercises: ? } \\
\text { nr. of repetitions: } 1 \\
\text { exercises described: no } \\
\text { feedback: no }\end{array}$ & $\begin{array}{l}\text { TL: REP } \\
\text { nr. of repetitions: ? } \\
\text { reference of optimal } \\
\text { motion: yes } \\
\text { feedback: yes, subjects } \\
\text { received a detailed } \\
\text { description of ideal } \\
\text { pattern and corrective } \\
\text { instructions }\end{array}$ \\
\hline Schöllhorn, & Players from the $5^{\text {th }}$ and $7^{\text {th }}$ & Supplemental & Soccer: goal & Points scored over & 6 weeks & nr. of exercises: ? & TL: MSE \\
\hline
\end{tabular}




\begin{tabular}{|c|c|c|c|c|c|c|c|}
\hline $\begin{array}{l}2006 \text { (exp. 2) } \\
\text { PPRC: } \\
\text { DL vs TL }\end{array}$ & $\begin{array}{l}\text { German national soccer } \\
\text { division }(\mathrm{M}) \text {. } \\
\text { Allocation based on pre-test } \\
\text { scores. } \\
\text { DL: } \mathrm{n}=9 \\
\text { TL: } \mathrm{n}=9\end{array}$ & $\begin{array}{l}\text { to normal } \\
\text { club training }\end{array}$ & shooting & $\begin{array}{l}35 \text { trials divided } \\
\text { over } 7 \text { initial ball } \\
\text { locations (optimal } \\
\text { target locations } \\
\text { recieved more } \\
\text { points) }\end{array}$ & $\begin{array}{l}2 \text { sessions week }{ }^{-1} \\
(25 \text { min, no goal } \\
\text { shooting during } \\
\text { regular training) } \\
\text { retention test: } 1 \\
\text { year after post- } \\
\text { test }\end{array}$ & $\begin{array}{l}\text { nr. of repetitions: } 1 \\
\text { exercises described: no, } \\
\text { only sources of } \\
\text { variation } \\
\text { feedback: ? }\end{array}$ & $\begin{array}{l}\text { nr. of repetitions: } 5-10 \\
\text { per exercise } \\
\text { feedback after every } \\
\text { shot: error descriptions, } \\
\text { movement-oriented } \\
\text { corrections, metaphoric } \\
\text { instructions }\end{array}$ \\
\hline $\begin{array}{l}\text { Beckmann, } \\
2006 \\
\text { PPRC: } \\
\text { DL vs TL }\end{array}$ & $\begin{array}{l}\text { Sports science students }(12 \\
\mathrm{M}+12 \mathrm{~F} \text {, age } 22.1 \pm 3.8) \\
\text { No experience in shot put. } \\
\text { Allocation to groups was } \\
\text { based on pre-test scores. } \\
\text { DL: } \mathrm{n}=12(6 \mathrm{M}+6 \mathrm{~F}) \\
\text { TL: } \mathrm{n}=12(6 \mathrm{M}+6 \mathrm{~F})\end{array}$ & $\begin{array}{l}\text { University } \\
\text { sports class }\end{array}$ & $\begin{array}{l}\text { Shot put (mass } \\
\text { of the shot: } F= \\
3,4 \mathrm{~kg}, M= \\
6.25 \mathrm{k} \text { ) }\end{array}$ & $\begin{array}{l}\text { The average shot } \\
\text { distance of three } \\
\text { trials. Sufficient } \\
\text { recovery time } \\
\text { between trials. }\end{array}$ & $\begin{array}{l}4 \text { weeks } \\
2 \text { sessions week } \\
(60 \text { min }) \\
\text { retention tests: } 2 \\
\text { and } 4 \text { weeks after } \\
\text { post-test }\end{array}$ & $\begin{array}{l}\text { nr. of exercises: } \pm 30 \text { per } \\
\text { session } \\
\text { nr. of repetitions: } 1 \\
\text { exercises described: no, } \\
\text { only sources of } \\
\text { variation } \\
\text { feedback: no }\end{array}$ & $\begin{array}{l}\text { TL: MSE } \\
\text { nr. of repetitions: } 10-15 \\
\text { per exercise } \\
\text { reference of optimal } \\
\text { motion: yes } \\
\text { feedback: yes, corrective } \\
\text { instructions }\end{array}$ \\
\hline $\begin{array}{l}\text { Schöllhorn, } \\
2008 \text { (exp. 1) } \\
\text { PPRC: } \\
\text { DL vs TL }\end{array}$ & $\begin{array}{l}3 \mathrm{~F}+9 \mathrm{M} \text { well trained } \\
\text { tennis players (tennis } \\
\text { experience: between } 17 \text { and } \\
34 \text { years in regional tennis } \\
\text { league). } \\
\text { Allocation to groups was } \\
\text { based on pre-test scores. } \\
\text { DL: } \mathrm{n}=6 \\
\text { TL: } \mathrm{n}=6\end{array}$ & $\begin{array}{l}\text { Supplemental } \\
\text { to normal } \\
\text { club training }\end{array}$ & Tennis service & $\begin{array}{l}3 \times 4 \text { services from } \\
\text { the left and right side } \\
\text { towards different } \\
\text { target zones. } \\
\text { According to the } \\
\text { tactical advantage of } \\
\text { each zone, the } \\
\text { service received } \\
1 / 2 / 3 / 4 \text { points. Sum } \\
\text { of the points is the } \\
\text { performance } \\
\text { variable. }\end{array}$ & $\begin{array}{l}6 \text { weeks } \\
2 \text { sessions week }{ }^{-1} \\
\text { retention test: } 2 \\
\text { weeks after } \\
\text { intervention }\end{array}$ & $\begin{array}{l}\text { nr. of exercises: } \pm 90 \\
\text { services per session } \\
\text { nr. of repetitions: ? } \\
\text { exercises described: no, } \\
\text { only sources of } \\
\text { variation } \\
\text { feedback: no }\end{array}$ & $\begin{array}{l}\text { TL: MSE } \\
\text { nr. of exercises: } \pm 90 \\
\text { services per session } \\
\text { nr. of repetitions: ? } \\
\text { reference of optimal } \\
\text { motion: yes } \\
\text { feedback: yes, corrective } \\
\text { instructions }\end{array}$ \\
\hline $\begin{array}{l}\text { Schöllhorn, } \\
2009 \\
\text { PPRC: } \\
\text { DL vs TL }\end{array}$ & $\begin{array}{l}36 \mathrm{M}, 21 \mathrm{~F} \text { novice high } \\
\text { jumpers, age } 22.8 \pm 2.2 \text {. } \\
\text { Allocation was based on the } \\
\text { results of the pre-test. } \\
\text { DL: } \mathrm{n}=19 \\
\text { TL: } \mathrm{n}=19\end{array}$ & $?$ & $\begin{array}{l}\text { Fosbury flop } \\
\text { and jump and } \\
\text { reach test. }\end{array}$ & $\begin{array}{l}\text { best performance of } \\
\text { two trials (maximal } \\
\text { height) }\end{array}$ & $\begin{array}{l}4 \text { weeks } \\
2 \text { sessions week }{ }^{-1} \\
\text { retention: } 10 \\
\text { days after post- } \\
\text { test }\end{array}$ & $\begin{array}{l}\text { nr. of exercises: ? } \\
\text { nr. of repetitions: } 1 \\
\text { exercises described: no, } \\
\text { only sources of } \\
\text { variation } \\
\text { feedback: no }\end{array}$ & $\begin{array}{l}\text { TL: MSE } \\
\text { nr. of exercises: ? } \\
\text { nr. of repetitions: ? } \\
\text { reference of optimal } \\
\text { motion: yes } \\
\text { feedback: yes, corrective } \\
\text { instructions }\end{array}$ \\
\hline $\begin{array}{l}\text { Schöllhorn, } \\
2010\end{array}$ & $\begin{array}{l}\text { Athletic club athletes, age } \\
13.2 \pm 1.7\end{array}$ & $\begin{array}{l}\text { Supplemental } \\
\text { to normal }\end{array}$ & $60 \mathrm{~m}$ hurdle race & $\begin{array}{l}\text { Time to finish } \\
\text { (measured with light }\end{array}$ & $\begin{array}{l}6 \text { weeks } \\
4 \text { sessions week }{ }^{-1}\end{array}$ & $\begin{array}{l}\text { nr. of exercises: ? } \\
\text { nr. of repetitions: } 1\end{array}$ & $\begin{array}{l}\text { TL: MSE } \\
\text { nr. of exercises: ? }\end{array}$ \\
\hline
\end{tabular}




\begin{tabular}{|c|c|c|c|c|c|c|c|}
\hline $\begin{array}{l}\text { PPC: } \\
\text { DL vs TL }\end{array}$ & $\begin{array}{l}\text { DL: } \mathrm{n}=15 \\
\text { TL: } \mathrm{n}=13\end{array}$ & club training & & barriers) & $\begin{array}{l}\text { (90min of which } \\
\text { 30min for hurdle } \\
\text { training) }\end{array}$ & $\begin{array}{l}\text { exercises described: no, } \\
\text { only sources of } \\
\text { variation } \\
\text { gradual DL: every } \\
\text { exercise was combined } \\
\text { with a new instruction } \\
\text { that was related to the } \\
\text { previous exercise, but } \\
\text { with an additional task. } \\
\text { feedback: no }\end{array}$ & $\begin{array}{l}\text { nr. of repetitions: } 3 \text { per } \\
\text { exercise } \\
\text { reference of optimal } \\
\text { motion: yes } \\
\text { feedback: yes, corrective } \\
\text { instructions and } \\
\text { explanations about } \\
\text { technique of world class } \\
\text { athletes through video } \\
\text { and photographs. }\end{array}$ \\
\hline $\begin{array}{l}\text { Beckmann, } \\
2010 \\
\text { PPRC: } \\
\text { DL1 vs DL2 } \\
\text { vs DL3 vs CI }\end{array}$ & $\begin{array}{l}\text { Experienced hockey } \\
\text { players. } \\
\text { DL1: } \mathrm{n}=9 \\
\text { DL2: } \mathrm{n}=9 \\
\text { DL3: } \mathrm{n}=9 \\
\text { CI: } \mathrm{n}=9\end{array}$ & $\begin{array}{l}\text { Supplemental } \\
\text { to normal } \\
\text { club training }\end{array}$ & $\begin{array}{l}\text { Hockey: push } \\
\text { and flick } \\
\text { towards goal } \\
\text { (targets bottom } \\
\text { right and top left } \\
\text { respectively). }\end{array}$ & $\begin{array}{l}\text { Target precision } \\
\text { (measured with an } \\
\text { optic measurement } \\
\text { system) }\end{array}$ & $\begin{array}{l}6 \text { weeks } \\
2 \text { sessions week }{ }^{-1} \\
\text { retention: } 2 \text { and } 4 \\
\text { weeks after post- } \\
\text { test }\end{array}$ & $\begin{array}{l}\text { nr. of exercises: } 20 \text { for } \\
\text { push and } 20 \text { for flick } \\
\text { DL1: targets were } \\
\text { varied in randomized } \\
\text { order and no targets } \\
\text { were aimed twice. } \\
\text { DL2: no target } \\
\text { variations, but } \\
\text { movement variations } \\
\text { DL3: combination of } \\
\text { DL1 and DL2 } \\
\text { nr. of repetitions: } 1 \\
\text { exercises describd: no } \\
\text { feedback: no }\end{array}$ & $\begin{array}{l}\text { CI (no variations, but } \\
\text { subjects practiced the } \\
\text { push and flick in } \\
\text { randomized order) } \\
\text { nr. of repetitions: } 20 \text { for } \\
\text { push and } 20 \text { for flick } \\
\text { reference of optimal } \\
\text { motion: no }\end{array}$ \\
\hline $\begin{array}{l}\text { Savelsbergh, } \\
2010 \\
\text { PPC: } \\
\text { DL vs TL }\end{array}$ & $\begin{array}{l}\text { Adult recreational ice } \\
\text { skaters }(\mathrm{M}) \text {, age } 44.2 \pm 9.8 \\
\text { with } 100-\mathrm{m} \text { time }>13 \mathrm{~s} . \\
\text { Allocation to groups was } \\
\text { based on pre-test scores. } \\
\text { DL: } \mathrm{n}=9 \\
\text { TL: } \mathrm{n}=9\end{array}$ & $\begin{array}{l}\text { Supplemental } \\
\text { to normal } \\
\text { club training }\end{array}$ & $\begin{array}{l}\text { Ice skating start } \\
\text { in a straight line } \\
\text { from a stand still } \\
\text { position. }\end{array}$ & $\begin{array}{l}\text { Split times were } \\
\text { taken at } 5 \mathrm{~m}, 10 \mathrm{~m} \text {, } \\
25 \mathrm{~m} \text { and } 49 \mathrm{~m} \text {. Five } \\
\text { trials were } \\
\text { performed in a } 1 \\
\text { hour period. }\end{array}$ & $\begin{array}{l}1 \text { week } \\
3 \text { sessions of } 60 \\
\text { min }\end{array}$ & $\begin{array}{l}\text { nr. of exercises: } 14 \\
\text { (different start } \\
\text { positions) } \\
\text { nr. of repetitions: } 1 \\
\text { exercises describd: yes } \\
\text { feedback: no }\end{array}$ & $\begin{array}{l}\text { TL: REP } \\
\text { nr. of repetitions: } 14 \\
\text { feedback: yes, corrective } \\
\text { intstructions on starting } \\
\text { position } \\
\text { reference of optimal } \\
\text { motion: yes }\end{array}$ \\
\hline $\begin{array}{l}\text { Schöllhorn, } \\
2012\end{array}$ & $\begin{array}{l}8^{\text {th }} \text { division of German } \\
\text { soccer league. } \\
\text { DLr: } n=4 \text { (age } 24.5 \pm 2.1 \text {, }\end{array}$ & $\begin{array}{l}\text { Supplemental } \\
\text { to normal } \\
\text { club training }\end{array}$ & $\begin{array}{l}\text { Soccer: ball } \\
\text { control test and } \\
\text { goal shooting }\end{array}$ & $\begin{array}{l}\text { Distance between } \\
\text { initial ball contact } \\
\text { and the position of }\end{array}$ & $\begin{array}{l}4 \text { weeks } \\
2 \text { sessions week }{ }^{-1}\end{array}$ & $\begin{array}{l}\text { nr. of exercises: } 20 \\
\text { exercises on ball control } \\
\text { and } 20 \text { on goal shooting }\end{array}$ & $\begin{array}{l}\text { TL: REP } \\
\text { nr. of repetitions: } 20 \\
\text { repetitions of ball control }\end{array}$ \\
\hline
\end{tabular}




\begin{tabular}{|c|c|c|c|c|c|c|c|}
\hline $\begin{array}{l}\text { PPRC: } \\
\text { Dlr vs Dlb vs } \\
\text { TL }\end{array}$ & $\begin{array}{l}\text { soccer experience } 20.5 \pm \\
1.0 \text { ) } \\
\text { DLb: } \mathrm{n}=4 \text { (age } 24.5 \pm 2.1 \text {, } \\
\text { soccer experience } 20.8 \pm \\
3.4 \text { ) } \\
\mathrm{TL}: \mathrm{n}=4 \text { (age } 23.8 \pm 3.9 \text { ) } \\
\text { soccer experience } 18.5 \pm \\
4.7 \text { ) }\end{array}$ & & test. & $\begin{array}{l}\text { the ball after control } \\
\text { when receiving the } \\
\text { ball. } \\
\text { Points scored over } \\
35 \text { trials divided } \\
\text { over } 7 \text { initial } \\
\text { locations (optimal } \\
\text { targets received } \\
\text { more points). }\end{array}$ & & $\begin{array}{l}\text { per session } \\
\text { nr. of repetitions: } 1 \\
\text { exercises described: yes } \\
\text { feedback: no } \\
\text { DLr: random changes } \\
\text { between exercises for } \\
\text { ball control and goal } \\
\text { shooting } \\
\text { DLb: blocked sequence } \\
\text { of exercises for ball } \\
\text { control and goal } \\
\text { shooting }\end{array}$ & $\begin{array}{l}\text { and } 20 \text { of goal shooting } \\
\text { per session } \\
\text { reference of optimal } \\
\text { motion: yes }\end{array}$ \\
\hline $\begin{array}{l}\text { Reynoso, } \\
2013 \\
\text { PPRC: } \\
\text { DL vs TL }\end{array}$ & $\begin{array}{l}\text { Students with no volleyball } \\
\text { experience. } 11 \mathrm{~F}, 21 \mathrm{M} \\
\text { DL: } \mathrm{n}=10 \text { (age } 21.0 \pm \\
0.94 \text { ) } \\
\text { TL: } \mathrm{n}=11 \text { (age } 22.0 \pm \\
2.10 \text { ) } \\
\text { Before the pre-test, all } \\
\text { subjects received an } \\
\text { audiovisual introduction to } \\
\text { the correct execution of the } \\
\text { service (reference to } \\
\text { guidelines provided). }\end{array}$ & $?$ & $\begin{array}{l}\text { Volleyball } \\
\text { service test. } \\
4 \text { sets of } 8 \\
\text { services to a } \\
\text { specified target. }\end{array}$ & $\begin{array}{l}\text { Speed and accurcy } \\
\text { of the service } \\
\text { (measured with radar } \\
\text { gun and video } \\
\text { camera). }\end{array}$ & $\begin{array}{l}3 \text { weeks } \\
11 \text { seesions }\end{array}$ & $\begin{array}{l}\text { nr. of exercises: } 3 \text { sets of } \\
15 \text { exercises per session } \\
\text { nr. of repetitions: } 1 \\
\text { exercises described: no } \\
\text { feedback: in the first } \\
\text { two sessions audiovisual } \\
\text { information was } \\
\text { supported with verbal } \\
\text { info when the subjects } \\
\text { requested it. }\end{array}$ & $\begin{array}{l}\text { TL: REP } \\
\text { nr. of repetitions: } 3 \text { sets } \\
\text { of } 15 \text { repetitions per } \\
\text { session } \\
\text { feedback: no }\end{array}$ \\
\hline $\begin{array}{l}\text { James, } 2014 \mathrm{a} \\
\text { PPC: } \\
\text { DL vs TL }\end{array}$ & $\begin{array}{l}14 \mathrm{M}, 19 \mathrm{~F} \text { (age } 25.2 \pm 4.2) \\
\text { DL: } \mathrm{n}=16 \\
\text { REP: } \mathrm{n}=17\end{array}$ & $\begin{array}{l}\text { Laboratory } \\
\text { experiment }\end{array}$ & $\begin{array}{l}\text { Standing as still } \\
\text { as possible on } \\
\text { one/two legs } \\
\text { with eyes open, } \\
\text { looking at a dot } \\
\text { on the wall. }\end{array}$ & $\begin{array}{l}\text { RMSJ of the head } \\
\text { and CoM in AP and } \\
\text { ML directions }\end{array}$ & $\begin{array}{l}1 \text { session } \\
\text { pre-test, training } \\
\text { and post-test on } \\
\text { one day ( } 15 \mathrm{~min} \\
\text { seated rest } \\
\text { between training } \\
\text { and post-test). }\end{array}$ & $\begin{array}{l}\text { nr. of exercises } 15 \\
\text { postural training trials } \\
\text { of } 1 \text { min duration with } \\
\text { 30s rest between trials } \\
\text { exercises described: yes }\end{array}$ & $\begin{array}{l}\text { TL: REP } \\
\text { nr. of repetitions: } 15 \\
\text { postural training trials } \\
\text { that repeated the } 2-1 \text { eg } \\
\text { stance task. }\end{array}$ \\
\hline $\begin{array}{l}\text { James, } 2014 b \\
\text { PPRC: } \\
\text { DL vs TL }\end{array}$ & $\begin{array}{l}12 \mathrm{M}, 15 \mathrm{~F} \text { (age } 23.9 \pm 3.8) \\
\text { DL: } \mathrm{n}=13 \\
\text { REP: } \mathrm{n}=14\end{array}$ & $\begin{array}{l}\text { Laboratory } \\
\text { experiment }\end{array}$ & $\begin{array}{l}\text { Rotations of an } \\
\text { handle }\left(180^{\circ}\right) \\
\text { with extended } \\
\text { elbows by }\end{array}$ & $\begin{array}{l}\text { RMSJ of the hand } \\
\text { during the } \\
\text { movement }\end{array}$ & $\begin{array}{l}2 \text { weeks } \\
2 \text { sessions week }{ }^{-1} \\
\text { post-test: } 24 \mathrm{~h}\end{array}$ & $\begin{array}{l}\text { nr. of exercises: } 20 \text { per } \\
\text { sessions (trials of } 1 \text { min, } \\
1 \text { min rest between, self- } \\
\text { selected pace and range }\end{array}$ & $\begin{array}{l}\text { TL: REP } \\
\text { nr. of repetitions: } 20 \text { per } \\
\text { sessions (trials of } 1 \text { min, } \\
1 \text { min rest between, self- }\end{array}$ \\
\hline
\end{tabular}




\begin{tabular}{|c|c|c|c|c|c|c|c|}
\hline & & & $\begin{array}{l}\text { radioulnar and } \\
\text { shoulder } \\
\text { in/external } \\
\text { rotations. Goal } \\
\text { was to make } \\
\text { smooth } \\
\text { movements to } \\
\text { the beat of a } \\
\text { metronome (1 } \\
\text { and } 2 \mathrm{~Hz}) \text {. }\end{array}$ & & $\begin{array}{l}\text { after last training, } \\
\text { retention-test: } 2 \\
\text { weeks after post- } \\
\text { test } \\
, 20 \text { practice } \\
\text { trials of } 1 \text { min } \\
\text { per session ( } 1 \\
\text { min rest between } \\
\text { trials). }\end{array}$ & $\begin{array}{l}\text { of motion) } \\
\text { nr. of repetitions: } 1 \\
\text { exercises described: yes } \\
\text { feedback: no }\end{array}$ & $\begin{array}{l}\text { selected pace and range } \\
\text { of motion) } \\
\text { feedback: no (but they } \\
\text { received the smoothness } \\
\text { instruction each session) }\end{array}$ \\
\hline $\begin{array}{l}\text { Repšaitè, } \\
2015 \\
\text { PPC: } \\
\text { mixed DL- } \\
\text { OT vs OT }\end{array}$ & $\begin{array}{l}\text { Patients that had suffered a } \\
\text { cerebral infarction in the } \\
\text { left hemisphere who } \\
\text { followed occupational } \\
\text { therapy courses. } \\
9 \mathrm{M}, 18 \mathrm{~F} \text { (age } 73.9 \pm 7.7 \text { ) } \\
\text { mixed DL-OT: } \mathrm{n}=12 \\
\text { OT: } \mathrm{n}=15\end{array}$ & $\begin{array}{l}\text { Physical } \\
\text { medicine and } \\
\text { rehabilitation } \\
\text { department } \\
\text { (hospital), 10- } \\
14 \text { days after } \\
\text { stroke onset. }\end{array}$ & $\begin{array}{l}\text { Wolf motor } \\
\text { function test } \\
\text { which includes } \\
15 \text { functional } \\
\text { tasks that have } \\
\text { to be completed } \\
\text { within } 120 \mathrm{~s} \text {. }\end{array}$ & $\begin{array}{l}\text { Time on each of the } \\
\text { tests. }\end{array}$ & $\begin{array}{l}32 \text { days } \\
5 \text { sessions week }^{-1} \\
(30 \mathrm{~min}) . \text { Both } \\
\text { groups received } \\
\text { the same co- } \\
\text { interventions. }\end{array}$ & $\begin{array}{l}\text { mixed DL-OT } \\
3 \text { sessions OT week }{ }^{-1} \\
\text { and } 2 \text { sessions DL week } \\
1 \\
\text { modified tools of OT, no } \\
\text { specific descriptions } \\
\text { included of the } \\
\text { variations }\end{array}$ & $\begin{array}{l}\text { TL: OT, exercises and } \\
\text { tools for strengthening } \\
\text { upper limb muscles, } \\
\text { range-of-motion, fine } \\
\text { motor skills and } \\
\text { coordination } \\
\text { nr. of repetitions:? }\end{array}$ \\
\hline $\begin{array}{l}\text { Mateus, } 2015 \\
\text { PPC: } \\
\text { DL vs TL }\end{array}$ & $\begin{array}{l}\text { Physical education students } \\
\text { (age } 20.4 \pm 1.9 \text { ). } \\
\text { DL: } \mathrm{n}=38 \\
\text { TL: } \mathrm{n}=38\end{array}$ & $\begin{array}{l}\text { University } \\
\text { sports class }\end{array}$ & $\begin{array}{l}\text { Basketball: } \\
\text { technical skills } \\
\text { (agility test and } \\
\text { taco bell } \\
\text { challenge) and } \\
\text { tactical skills } \\
\text { (4v4 small sided } \\
\text { game). }\end{array}$ & $\begin{array}{l}\text { Technical skills: } \\
\text { total time to conduct } \\
\text { the tests. } \\
\text { Tactical skills were } \\
\text { assessed with a 4-a- } \\
\text { side game } \\
\text { (videorecording): } \\
\text { (un)successful } \\
\text { attempts were } \\
\text { counted for } 4 \text { actions } \\
\text { (triple threat } \\
\text { position, field goals, } \\
\text { give-and-go, } \\
\text { explore-1-on1- } \\
\text { game). }\end{array}$ & $\begin{array}{l}8 \text { weeks } \\
2 \text { sessions week }{ }^{-1} \\
(120 \text { min }) \\
\text { warm-up, small } \\
\text { sided games and } \\
\text { 5-a-side } \\
\text { basketball games } \\
\text { within each } \\
\text { session was the } \\
\text { same for both } \\
\text { groups. }\end{array}$ & $\begin{array}{l}\text { nr. of exercises: ? } \\
\text { nr. of repetitions: ? } \\
\text { exercises described: no } \\
\text { feedback:? }\end{array}$ & $\begin{array}{l}\text { TL: REP } \\
\text { nr. of repetitions: ? } \\
\text { feedback: ? } \\
\text { reference of optimal } \\
\text { motion: no }\end{array}$ \\
\hline
\end{tabular}




\begin{tabular}{|c|c|c|c|c|c|c|c|}
\hline $\begin{array}{l}\text { Hossner, } \\
2016 \text { (exp. 1) } \\
\text { PPC: } \\
\text { DL vs. } \\
\text { DL+FB vs. } \\
\text { TL }\end{array}$ & $\begin{array}{l}\text { Players (M) from a Swiss } \\
\text { soccer club. Allocation } \\
\text { based on pre-test scores, } \\
\text { age and soccer experience. } \\
\text { DL: } n=10 \\
\text { DL+FB: } n=9 \\
\text { TL }: n=9\end{array}$ & $\begin{array}{l}\text { Supplemental } \\
\text { to normal } \\
\text { club training. }\end{array}$ & $\begin{array}{l}\text { Soccer: } 16 \text { goal } \\
\text { shots ( } 8 \text { shots } \\
\text { from a left and } \\
\text { right position } \\
\text { subdivided into } \\
4 \text { shots each to a } \\
\text { target in the left } \\
\text { and right corner } \\
\text { of the goal (red } \\
\text { disks, } 0.2 \mathrm{~m} \\
\text { diameter). }\end{array}$ & $\begin{array}{l}\text { Shots were filmed: } \\
\text { average radial error } \\
\text { to target center. }\end{array}$ & $\begin{array}{l}6 \text { weeks } \\
2 \text { sessions week }{ }^{-1} \\
(30 \text { min) } \\
\text { post-test: } 1 \text { week } \\
\text { after last session } \\
\text { absent sessions: } \\
0.9 \pm 1.1 \text { (no } \\
\text { difference across } \\
\text { groups). }\end{array}$ & $\begin{array}{l}\text { DL: } \\
\text { nr. of exercises: } 30-35 \\
\text { nr. of repetitions: ? } \\
\text { exercises described: no, } \\
\text { only sources of } \\
\text { variation (initial only } 1 \\
\text { source of variation, later } \\
\text { combinations were } \\
\text { used) } \\
\text { feedback: no } \\
\text { DL+FB: same as DL } \\
\text { with individual } \\
\text { feedback when non- } \\
\text { optimal performance } \\
\text { was noticed that could } \\
\text { not be attributed to the } \\
\text { current task variant. } \\
\text { Augmented feedback } \\
\text { was also given to the } \\
\text { whole group. }\end{array}$ & $\begin{array}{l}\text { TL: MSE } \\
\text { 30-35 shots per session } \\
\text { nr. of repetitions per } \\
\text { exercise: ? } \\
\text { feedback: yes } \\
\text { reference of optimal } \\
\text { motion: yes }\end{array}$ \\
\hline $\begin{array}{l}\text { Hossner, } \\
2016 \text { (exp. 2) } \\
\text { PPRC: } \\
\text { DL vs. SL vs. } \\
\text { TL }\end{array}$ & $\begin{array}{l}\text { Sports science students ( } 13 \\
\mathrm{~F}, 23 \mathrm{M}) \text {. Allocation based } \\
\text { on pre-test score, age, } \\
\text { height, sex, shot-put } \\
\text { experience, motivation to } \\
\text { take part in the study. } \\
\text { DL: } \mathrm{n}=12 \\
\text { TL: } \mathrm{n}=12 \\
\text { SL: } \mathrm{n}=12\end{array}$ & $\begin{array}{l}\text { University } \\
\text { sports, } \\
\text { students } \\
\text { received } \\
\text { credits.. }\end{array}$ & $\begin{array}{l}\text { Shot put (mass } \\
\text { of the shot: } F= \\
4 \mathrm{~kg}, \mathrm{M}=6.25 \\
\mathrm{~kg} \text { ) }\end{array}$ & $\begin{array}{l}\text { Average distance of } \\
3 \text { shots (sufficient } \\
\text { recovery time } \\
\text { between trials) }\end{array}$ & $\begin{array}{l}4 \text { weeks } \\
2 \text { sessions week }{ }^{-1} \\
\text { (consecutive } \\
\text { days) } \\
\text { absent sessions: } \\
0.7 \pm 0.7 \text { (no } \\
\text { difference across } \\
\text { groups). } \\
\text { Post-test during } \\
\text { last session, } \\
\text { retention: } 2 \text { and } 4 \\
\text { weeks after last } \\
\text { session }\end{array}$ & $\begin{array}{l}\text { nr. of exercises: } 32 \text { per } \\
\text { session (last session: } 20 \text { ) } \\
\text { exercises described: no, } \\
\text { only sources of } \\
\text { variation, } 2 \text { sources } \\
\text { combined per practice } \\
\text { trial (random order) } \\
\text { Exercises were } \\
\text { explained with } \\
\text { illustrations } \\
\text { nr. of repetitions: } 1 \\
\text { feedback: no }\end{array}$ & $\begin{array}{l}\text { TL: MSE } \\
\text { nr. of exercises: ? } \\
\text { nr. of repetitions: ? ( } 32 \\
\text { trials in total, last } \\
\text { session: 20) } \\
\text { reference of optimal } \\
\text { motion: yes } \\
\text { feedback: yes } \\
\text { SL: same practice } \\
\text { variants as DL, only the } \\
\text { order of the variants was } \\
\text { different: the sequence of } \\
\text { variants was determined } \\
\text { in order to minimize the } \\
\text { difference between } \\
\text { subsequent variants. }\end{array}$ \\
\hline
\end{tabular}




\begin{tabular}{|c|c|c|c|c|c|c|c|}
\hline $\begin{array}{l}\text { Pabel, } 2017 \\
\text { CRT-PO: } \\
\text { DL vs. TL }\end{array}$ & $\begin{array}{l}\text { Third-year students in a } \\
\text { preclinical course in } \\
\text { operative dentistry } \\
\text { (Germany). Both groups } \\
\text { had the same laboratory, but } \\
\text { no clinical experience. } \\
\text { DL: } n=32 \\
\text { TL: } n=41\end{array}$ & $\begin{array}{l}\text { University } \\
\text { course on } \\
\text { operative } \\
\text { dentistry. }\end{array}$ & $\begin{array}{l}\text { Preparation of a } \\
\text { gold partial } \\
\text { crown } \\
\text { (dentistry) on } \\
\text { training models } \\
\text { of the upper and } \\
\text { lower jaw fixed } \\
\text { in phantom } \\
\text { heads. }\end{array}$ & $\begin{array}{l}\text { The exam consisted } \\
\text { of preparing a gold } \\
\text { crown on tooth } 46 \\
\text { within } 90 \text { min. Four } \\
\text { examiners evaluated } \\
\text { the preparation } \\
\text { anonymously and } \\
\text { independent. Criteria } \\
\text { for exam failure are } \\
\text { indicated. Pass/fail } \\
\text { was the performance } \\
\text { variable. }\end{array}$ & $\begin{array}{l}4 \text { days } \\
4 \text { hours training } \\
\text { per day }\end{array}$ & $\begin{array}{l}\text { All subjectes viewed a } \\
\text { video demo with verbal } \\
\text { explanations before the } \\
\text { training. } \\
\text { nr. of exercises: } 5 \text { day }^{-1} \\
\text { nr. of repetitions: } 30 \\
\text { min per exercise } \\
\text { exercises described: yes } \\
\text { feedback: no }\end{array}$ & $\begin{array}{l}\text { All subjectes viewed a } \\
\text { video demo with verbal } \\
\text { explanations and } \\
\text { received demonstration } \\
\text { models of an 'ideal' } \\
\text { preparation and } \\
\text { assessment criteria: the } \\
\text { ideal dimensions and } \\
\text { parameters. } \\
\text { TL: MSE } \\
\text { nr. of exercsises: ? } \\
\text { nr. of repetitions: ? } \\
\text { feedback: yes (oral and } \\
\text { written) }\end{array}$ \\
\hline $\begin{array}{l}\text { Pabel, } 2018 \\
\text { PPRC: } \\
\text { DL vs TL }\end{array}$ & $\begin{array}{l}\text { Children 6-9 years from } 1 \\
\text { school (Germany). } \\
\text { Allocation was stratified on } \\
\text { first/second grade. } \\
\text { DL: } \mathrm{n}=18 \\
\text { TL: } \mathrm{n}=18\end{array}$ & $\begin{array}{l}\text { School-based } \\
\text { intervention: } \\
\text { during lunch } \\
\text { break at the } \\
\text { school's } \\
\text { washrooms. }\end{array}$ & Tooth brushing & $\begin{array}{l}\text { Evaluated by a } \\
\text { blinded examiner on } \\
\text { two parameters: } \\
\text { gingival } \\
\text { inflammation (PBI) } \\
\text { and plaque scores } \\
\text { (T-QHI). }\end{array}$ & $\begin{array}{l}15 \text { working days } \\
\text { ( } 3 \text { intervals of } 2 \\
\text { days each). }\end{array}$ & $\begin{array}{l}\text { All children were given } \\
\text { a toothbrush (changed } \\
\text { every } 21 \text { days), no other } \\
\text { oral hygiene products } \\
\text { were allowed (brushing } \\
\text { at home could not be } \\
\text { controlled). } \\
\text { Initial verbal instruction } \\
\text { and demonstration on a } \\
\text { model. } \\
\text { nr. of exercises: } 15 \\
\text { (1 per day) } \\
\text { nr. of repetitions: } 3 \text { min } \\
\text { exercises described: yes } \\
\text { feedback: no }\end{array}$ & $\begin{array}{l}\text { TL: REP } \\
\text { All children were given a } \\
\text { toothbrush (changed } \\
\text { every } 21 \text { days), no other } \\
\text { oral hygiene products } \\
\text { were allowed (brushing } \\
\text { at home could not be } \\
\text { controlled). } \\
\text { Initial verbal instruction } \\
\text { and demonstration on a } \\
\text { model. } \\
\text { nr. of repetitions: } 3 \text { min } \\
\text { reference to optimal } \\
\text { motion: yes } \\
\text { feedback: yes }\end{array}$ \\
\hline $\begin{array}{l}\text { Santos, } 2018 \\
\text { PPC: } \\
\text { DL vs TL }\end{array}$ & $\begin{array}{l}\text { Portuguese youth soccer } \\
\text { players (two different U13 } \\
\text { and U15 teams at regional } \\
\text { level). } \\
\text { DL-U13: } \mathrm{n}=10 \text { (age } 11.1 \pm \\
0.5 \text {, experience } 4.4 \pm 2.9) \\
\text { DL-U15: } \mathrm{n}=10(\text { age } 13.1 \pm \\
0.3 \text {, experience } 7.1 \pm 1.5) \\
\text { TL-U13: } \mathrm{n}=10 \text { (age } 11.4 \pm\end{array}$ & $\begin{array}{l}\text { Supplemental } \\
\text { to normal } \\
\text { club training. }\end{array}$ & $\begin{array}{l}\text { Soccer: } 5 \text { vs. } 5 \\
\text { small sided } \\
\text { game, } 2 \\
\text { bouts of } 6 \mathrm{~min} \\
(3 \mathrm{~min} \\
\text { rest between })\end{array}$ & $\begin{array}{l}\text { Games were } \\
\text { recorded and } \\
\text { behavior was } \\
\text { assessed with } \\
\text { notational analysis. } \\
\text { Fails, attempts, } \\
\text { fluency, versatility } \\
\text { and originality } \\
\text { occurrences were }\end{array}$ & $\begin{array}{l}5 \text { months } \\
3 \text { sessions week }^{-1} \\
(30 \text { min before } \\
\text { the regular club } \\
\text { training) }\end{array}$ & $\begin{array}{l}\text { nr. of exercises: ? } \\
\text { nr. of repetitions: ? } \\
\text { exercises described: yes } \\
\text { (sources of variation } \\
\text { and many examples of } \\
\text { each) } \\
\text { feedback: no }\end{array}$ & $\begin{array}{l}\text { TL: small-sided-games } \\
\text { with fewer variations } \\
\text { than DL } \\
\text { nr. of repetitions:? } \\
\text { feedback:? }\end{array}$ \\
\hline
\end{tabular}


0.5 , experience $5.3 \pm 2.5)$

TL-U15: $\mathrm{n}=10$ (age $13.0 \pm$

0.8 , experience $6.8 \pm 1.6$ )

\begin{tabular}{|c|c|c|c|c|c|c|c|}
\hline & $\begin{array}{l}0.5, \text { experience } 5.3 \pm 2.5) \\
\text { TL-U15: } \mathrm{n}=10(\text { age } 13.0 \pm \\
0.8, \text { experience } 6.8 \pm 1.6)\end{array}$ & & & $\begin{array}{l}\text { recorded for passes, } \\
\text { dribbles and shots. }\end{array}$ & & & \\
\hline $\begin{array}{l}\text { Coutinho, } \\
2018 \\
\text { CRPP: } \\
\text { DL vs TL }\end{array}$ & $\begin{array}{l}\text { Portugese youth soccer } \\
\text { players (attackers only) } \\
\text { from two teams. } \\
\text { DL-U15: } \mathrm{n}=9 \text { (age } 14.2 \pm \\
08, \text { experience } 6.4 \pm 3.2) \\
\text { DL-U17: } \mathrm{n}=6(\text { age } ?, \\
\text { experience } 6.4 \pm 3.2) \\
\text { TL-U15: } \mathrm{n}=9(\text { age } 13.9 \pm \\
0.5 \text {, experience } 6.1 \pm 3.1) \\
\text { TL-U17: } \mathrm{n}=6(\text { age } 16.1 \pm \\
0.7, \text { experience } 8.0 \pm 2.1)\end{array}$ & $\begin{array}{l}\text { Supplemental } \\
\text { to normal } \\
\text { club training. }\end{array}$ & $\begin{array}{l}\text { Soccer: } \\
\text { technical skills } \\
\text { (vertical jump, } \\
\text { speed, agility) } \\
\text { and tactical } \\
\text { behaviour ( } 5 \text { vs. } \\
5 \text { small sided } \\
\text { game, } 3 \text { bouts of } \\
6 \text { min ( } 3 \text { min } \\
\text { rest) }\end{array}$ & $\begin{array}{l}\text { Vertical jump: } \\
\text { counter movement. } \\
\text { Speed: } 30 \mathrm{~m} \text { sprint } \\
\text { test. Agility: } \\
\text { repeated change of } \\
\text { direction task: } \\
6 \times 20 \mathrm{~m} \text { sprints with } 4 \\
100^{\circ} \text { change of } \\
\text { direction (optical } \\
\text { timing system used } \\
\text { for all tests). } \\
\text { Games were } \\
\text { recorded and } \\
\text { assessed with } \\
\text { notational analysis. } \\
\text { Fails, attempts, } \\
\text { fluency, versatility } \\
\text { and originality } \\
\text { occurrences for } \\
\text { passes, dribbles and } \\
\text { shots. }\end{array}$ & $\begin{array}{l}10 \text { weeks } \\
2 \text { sessions week }{ }^{-1} \\
(25 \text { min } \\
\text { intervention }+65 \\
\text { min regular } \\
\text { training) } \\
\text { intervention: } 10 \\
\text { min physical } \\
\text { literacy }+15 \text { min } \\
\text { small-sided } \\
\text { gamess }\end{array}$ & $\begin{array}{l}\text { nr. of exercises: ? } \\
\text { nr. of repetitions: ? } \\
\text { exercises described: yes } \\
\text { (sources of variation } \\
\text { and many examples of } \\
\text { each) } \\
\text { feedback: no }\end{array}$ & $\begin{array}{l}\text { TL: regular club training } \\
\text { nr. of exercises: ? } \\
\text { nr. of repetitions: ? } \\
\text { feedback: ? }\end{array}$ \\
\hline $\begin{array}{l}\text { Bozkurt, } \\
2018 \\
\text { PPC: } \\
\text { DL vs TL }\end{array}$ & $\begin{array}{l}\text { Turkish soccer players (U15 } \\
\text { team) } \\
\text { DL: } n=6 \\
\text { TL: } \mathrm{n}=6\end{array}$ & $\begin{array}{l}\text { Supplemental } \\
\text { to normal } \\
\text { club training. }\end{array}$ & $\begin{array}{l}\text { Soccer: } \\
\text { technical skills } \\
\text { test battery }\end{array}$ & $\begin{array}{l}\text { Passing: Mor- } \\
\text { Christian soccer } \\
\text { passing test, German } \\
\text { Football Association } \\
\text { agility and driblling } \\
\text { test, feet juggling } \\
\text { test. }\end{array}$ & $\begin{array}{l}4 \text { weeks } \\
3 \text { sessions week }^{-1} \\
8 / 12 \text { players } \\
\text { attended the full } \\
\text { program }\end{array}$ & $\begin{array}{l}\text { nr. of exercises: } 9 \\
\text { exercises for target- } \\
\text { passing, } 9 \text { for dribbling } \\
\text { and } 9 \text { for feet-juggling } \\
\text { techniques (blocked } \\
\text { order) } \\
\text { nr. of repetitions: ? } \\
\text { exercises described: no } \\
\text { (only sources of } \\
\text { variation) } \\
\text { feedback: no }\end{array}$ & $\begin{array}{l}\text { TL: MSE } \\
\text { nr. of exercises: } 9 \\
\text { exercises for target- } \\
\text { passing, } 9 \text { for dribbling } \\
\text { and } 9 \text { for feet-juggling } \\
\text { techniques (blocked } \\
\text { order) } \\
\text { reference to optimal } \\
\text { motions: no } \\
\text { nr. of repetitions:? } \\
\text { feedback: yes }\end{array}$ \\
\hline
\end{tabular}

recorded for passes,

dribbles and shots. 


\begin{tabular}{|c|c|c|c|c|c|c|c|}
\hline $\begin{array}{l}\text { Weisner, } \\
2019 \\
\text { PPRC: } \\
\text { DL vs TL }\end{array}$ & $\begin{array}{l}\text { Assembly line workers. } \\
\text { DL: } \mathrm{n}=11(4 \mathrm{~F}, \text { age } 22-64 \text {, } \\
\text { median experience } 2) \\
\text { TL: } \mathrm{n}=11(4 \mathrm{~F}, \text { age } 21-61 \text {, } \\
\text { median experience } 3)\end{array}$ & $\begin{array}{l}\text { Field study: } \\
\text { industrial } \\
\text { engineering } \\
\text { training } \\
\text { center } \\
\text { (Institute of } \\
\text { Production } \\
\text { Systems, } \\
\text { Dortmund) }\end{array}$ & $\begin{array}{l}\text { Production of a } \\
\text { 2-speed-gearbox } \\
\text { in } 6 \text { assembly } \\
\text { cycles. }\end{array}$ & $\begin{array}{l}\text { Assembly cycle } \\
\text { times and assembly } \\
\text { errors (test duration } \\
=60 \text { min). }\end{array}$ & $\begin{array}{l}3 \text { weeks } \\
5 \text { sessions total } \\
\left(60 \text { min session }^{-1}\right)\end{array}$ & $\begin{array}{l}\text { nr. of products: } 28 \\
\text { nr. of exercises: ? } \\
\text { exercises described: no } \\
\text { (only sources of } \\
\text { variation) } \\
\text { feedback: no }\end{array}$ & $\begin{array}{l}\text { TL: REFA-Work } \\
\text { instructions (based on } \\
\text { optimal pattern) } \\
\text { feedback: yes }\end{array}$ \\
\hline
\end{tabular}

Abbreviations: $\exp =$ experiment, $P P C=$ pre-test-post-test design with control group, PPRC = pre-test-post-test design with retention test and control group, CRT-PO = cluster-randomized trial post-test only, CRPP: ckuster-randomized pre-test-post-test design, $M=$ male, $F=$ female, DL $=$ differential learning, TL $=$ traditional learning (REP and MSE), REP = repetitive practice, $R M S J=$ root-mean-square-jerk, CoM = center-of-mass, $A P=$ antero-posterior, $M L=$ media-lateral $M S E=$ methodological series of exercises, $O T=$ occupational therapy, ? = not described in the article/chapter or only generic statements regarding the content 
Twenty articles met the inclusion criteria, resulting in 25 experiments. DL has been used in a variety of contexts: (1) sport performance outcomes (shot put, high jump, hurdle racing, ice skating race) (Beckmann \& Shöllhorn, 2006; Hossner et al., 2016b; Savelsbergh et al., 2010; Schöllhorn, Beckmann, Janssen, et al., 2010); (2) technical skills in a single sports movement (service in volleyball/tennis, soccer: passing, shooting, ball control, hockey: goal shooting) (Beckmann, Winkel, \& Schöllhorn, 2010; Bozkurt, 2018; Hossner et al., 2016b; Reynoso, Solana, Vaillo, \& Hernandez, 2013; Schöllhorn et al., 2006, 2012; Schöllhorn, Humpert, Oelenberg, Michelbrink, \& Beckmann, 2008; Schöllhorn, Michelbrink, et al., 2009; Schollhorn, Sechelmann, Trockel, \& Westers, 2004); (3) tactical skills in a sport context (basketball, soccer) (Coutinho et al., 2018; Mateus, Santos, Vaz, Gomes, \& Leite, 2015; Santos et al., 2018); (4) fine motor skills (toothbrushing, dental surgery, handle rotation, balance) (James, 2014; James \& Conatser, 2014; Pabel et al., 2018, 2017; Weisner, Knittel, Jaitner, \& Deuse, 2018); and (5) upper limb neuromotor rehabilitation (Repšaitė et al., 2015). Mateus et al. (2015) and Coutinho et al. (2018) assessed the effects of DL on both technical and tactical skills. The majority of studies examined the effects of DL only directly after the intervention (acquisition effect), only 11/25 experiments included a retention test (learning effect). Much heterogeneity was present in the duration, frequency, amount of variability in DL, the variability in the control condition and characteristics of the participants (age, experience with the task).

Table 2 gives an overview of the risk of bias of each study (experiment). Concerning randomization, 14/25 experiments had a low risk of bias and the other were unclear, two studies used cluster randomization (high risk). Allocation concealment was unclear in all but one experiment where it was high risk of bias. Given the nature of the experiments, blinding of participants and personnel was not possible. Outcome assessment was blinded in 7/25 
experiments and unclear otherwise (blinded researcher or computerized registrations). Incomplete outcome data was high risk or unclear in $6 / 25$ experiments, the rest had low risk. Selective outcome reporting was high risk of bias in $9 / 25$ experiments (reported no means, standard deviations and/or statistics and did not respond to emails for further inquiry). Other reasons of bias were an incomplete description of the training/control intervention, outcome variables that are susceptible to subjective interpretation. With exception for the studies from the groups of Savelsbergh, James, Hossner and Pabel, risk of bias was overall high for all studies (fewer than 4/7 items with low risk of bias).

Table 2. Risk of bias analysis (+ = low risk, ? = unclear risk, - = high risk).

\begin{tabular}{|c|c|c|c|c|c|c|c|c|}
\hline First author, year & $\mathbf{A}$ & B & C & D & $\mathbf{E}$ & $\mathbf{F}$ & $\mathbf{G}$ & \\
\hline Schöllhorn, 2004 (exp. 1) & + & $?$ & & $?$ & $?$ & & & * \\
\hline Schöllhorn, 2004 (exp. 2) & + & ? & & ? & ? & & & $*$ \\
\hline Schöllhorn, 2004 (exp. 3) & + & ? & & ? & $?$ & & & \\
\hline Schöllhorn, 2006 (exp. 1) & ? & ? & & ? & + & & & * \\
\hline Schöllhorn, 2006 (exp. 2) & + & ? & & $?$ & + & & & $*$ \\
\hline Beckmann, 2006 & + & ? & & ? & + & & & * \\
\hline Schöllhorn, 2008 & + & ? & & ? & + & & & \\
\hline Schöllhorn, 2009 & + & ? & & ? & + & & & * \\
\hline Schöllhorn, 2010 & + & ? & & ? & + & & & \\
\hline Beckmann, 2010 & + & ? & & + & + & & & \\
\hline Savelsbergh, 2010 & + & ? & & + & ? & & & $*$ \\
\hline Schöllhorn, 2012 & ? & ? & & ? & - & + & & $*$ \\
\hline Reynoso, 2013 & + & ? & & ? & + & + & & * \\
\hline James, 2014a & ? & ? & & + & + & + & & * \\
\hline James, 2014b & $?$ & ? & & + & + & + & & * \\
\hline Mateus, 2015 & $?$ & ? & & ? & + & $t$ & & * \\
\hline Repšaitè, 2015 & ? & ? & & + & + & & & \\
\hline Hossner, 2016 (exp. 1) & + & ? & & ? & + & + & & * \\
\hline Hossner, 2016 (exp. 2) & + & ? & & $?$ & + & $t$ & & * \\
\hline Pabel, 2017 & - & - & & + & + & + & & * \\
\hline Pabel, 2018 & + & ? & & + & + & + & & * \\
\hline Bozkurt, 2018 & $?$ & ? & & $?$ & & & & * \\
\hline Santos, 2018 & $?$ & ? & & $?$ & + & & & * \\
\hline Coutinho, 2018 & - & - & & $?$ & + & + & & * \\
\hline Weisner, 2019 & $?$ & ? & . & $?$ & + & - & & \\
\hline
\end{tabular}

$\overline{A=\text { random sequence generation; } B=\text { allocation concealment }} ; C=$ blinding of participants and personnel; $D$ = blinding of outcome assessment; $E=$ incomplete outcome data; $F=$ selective reporting; $G=$ other bias; $*=$ study included in meta-analysis 
3.2.2. Quantitative synthesis of results and sensitivity analyses. Given the relatively low number of experiments and heterogeneity between them, no further selection on quality was done and all experiments that provided data were used in the meta-analysis.

Acquisition phase (post -pre, forest plot in Figure 2). Regarding performance outcomes in sport contexts, DL performed better than TL in 4/4 experiments with a relatively high overall effect size, however, the $95 \%$ CI included zero $(d=0.82,[-0.05,1.69])$. The study of Beckmann et al. (2006) was an outlier (also considered across the entire meta-analysis) and had a strong influence on this subgroup. It is likely that the true effect size is lower. Heterogeneity between effects was large $\left(I^{2}=81 \%\right)$, certainly when we consider that the study of Hossner et al. (2016, exp. 2) was a quasi replication of the study of Beckmann but the ratio between effect sizes was 10.5 , indicating the presence of unexplained factors or bias by the researchers. The type of performance outcome (speed vs. throwing distance) can be a potential unexplained factor. Compared to SL, DL improved less on performance outcomes $(d=-0.19,[-1.000 .62])$, but this was based on only one study. For technical skills in a sports context, most evidences were found but only compared to TL. The overall effect size and $95 \%$ CI for technical skills was moderate positive $(d=0.37,[0.17,0.58])$ and heterogeneity was small $\left(I^{2}=20 \%\right)$. DL performed on average better than TL in 13/14 experiments. Also for tactical behaviour in sports was a moderate positive overall effect size observed $(d=0.43$, $[0.05,0.81])$ and DL performed on average better in $4 / 5$ experiments. Heterogeneity was quite large $\left(I^{2}=81 \%\right)$. Regarding fine motor skills, DL performed on average better than TL in $3 / 4$ experiments, but the overall effect size was negative $(d=-0.12,[-1.04,0.79])$, largely due to a strong negative outlier (large heterogeneity, $I^{2}=97 \%$ ). The test for overall subgroup differences was not statistically significant $\left(\chi^{2}=4.05, p=0.40\right)$, but this may be because $3 / 5$ subgroups had very large variances due to low sample sizes. 


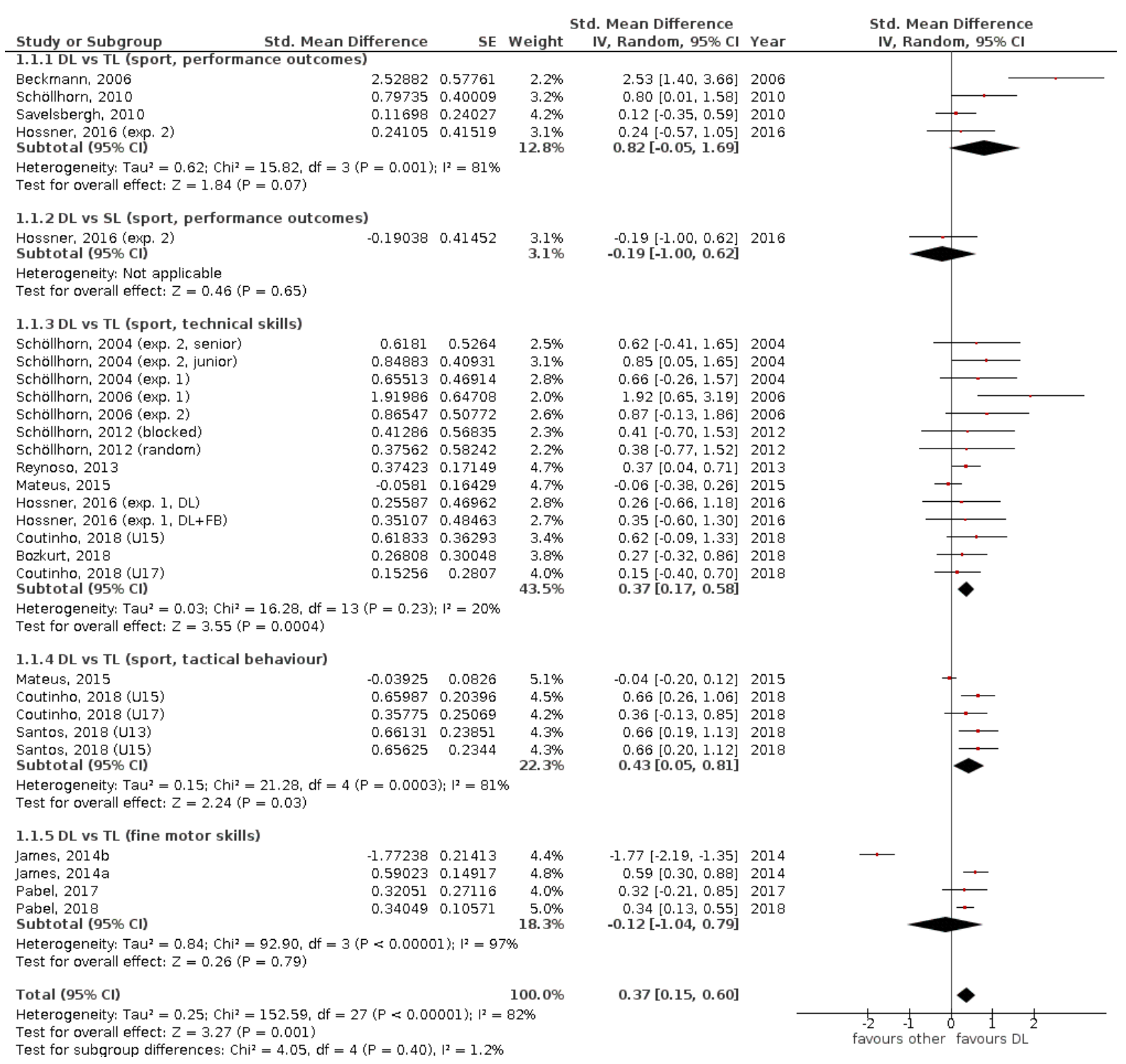

Figure 2: Forest plot for the effects of differential learning versus other methods grouped by category of movement task: acquisition (post-test vs. pre-test).

Learning phase (retention -pre, forest plot in Figure 3). Much less evidences could be found for the permanent learning effect after the cessation of DL. Similar to the acquisition effect for shot put training, both studies of Beckmann et al. (2006) and Hossner et al. (2016) found a better learning effect for DL compared to TL, but a very large discrepancy was observed for the effect sizes despite their similar designs. Compared to SL, DL performed on average worse, but the effect was small and only based on 1 study. For technical skills, 4/4 studies showed on average better learning effects for DL compared to TL $(d=0.51,[0.22$, 
0.81]). Regarding fine motor skills, $3 / 3$ studies showed superior effects for DL compared to TL with large effect sizes (overall effect: $d=1.14,[0.73,1.55]$ ). The test for overall subgroup differences was statistically significant at the $5 \%$ level $\left(\chi^{2}=10.84, p=0.01\right)$.

Averaged across all subgroup comparisosn, the effect of DL was much higher in the retention phase $(d=0.90,[0.50,1.30])$ than in the acquisition phase $(d=0.37,[0.15,0.60])$.

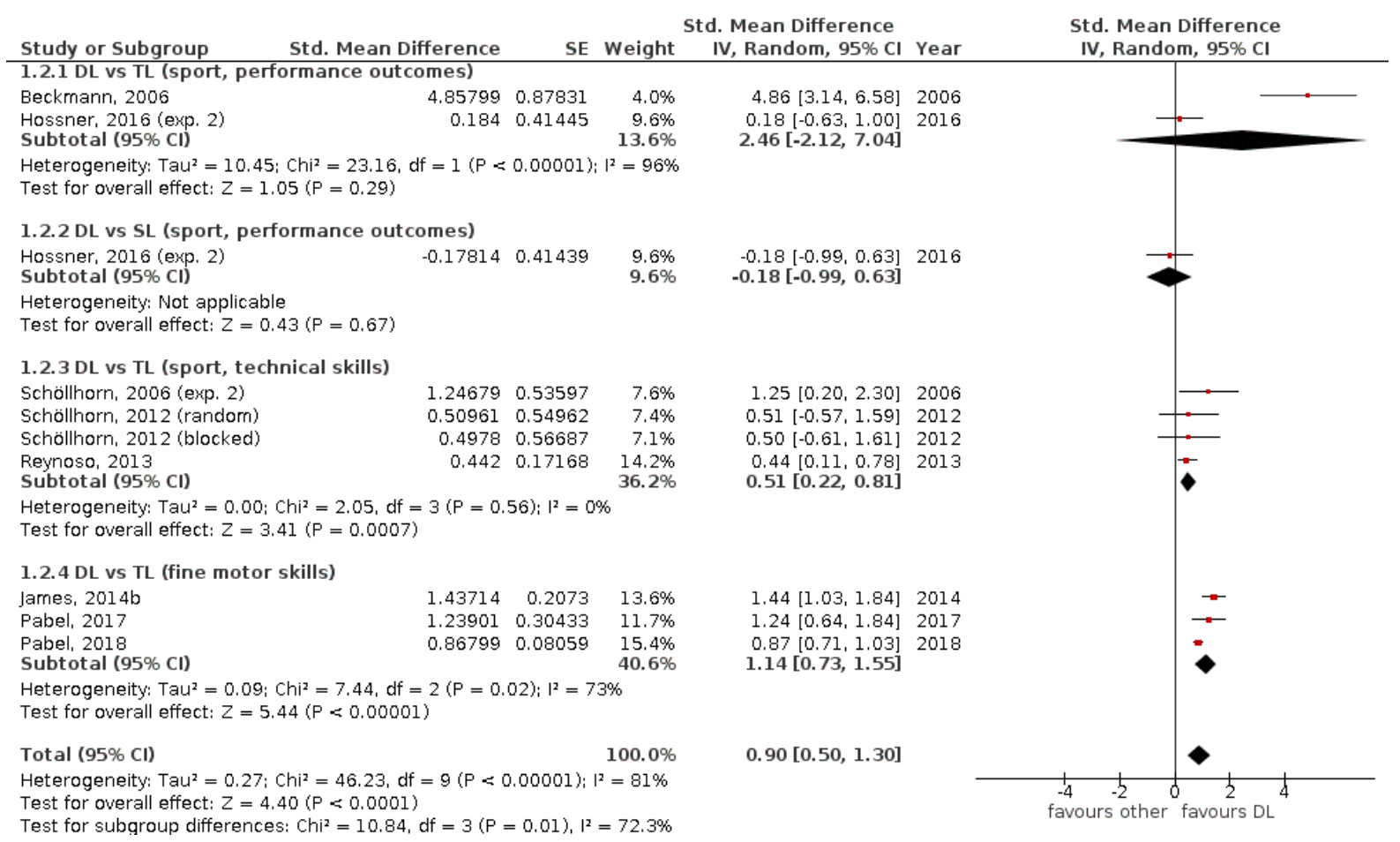

Figure 3: Forest plot for the effects of differential learning versus other methods grouped by category of movement task: learning (retention-test vs. pre-test).

Table 3 presents the results of the sensitivity analyses on the calculation of the effect size variances, using various levels of the pre-post correlation. The results are fairly robust under a wide range of plausible correlation coefficients. 
Table 3: Sensitivity analysis of the effect sizes [95\% CI] based on various levels of the pre-post correlation coefficient. The default estimate of $r=0.50$ is shown as reference (same as in forest plots).

\begin{tabular}{|c|c|c|c|}
\hline \multirow[t]{2}{*}{ Acquisition effect } & \multicolumn{3}{|c|}{ pre-post correlation } \\
\hline & $r=0.15$ & $r=\mathbf{0 . 5 0}$ & $r=0.85$ \\
\hline DL vs. TL (sport, performance outcomes) & $0.81[-0.12,1.74]$ & $0.82[-0.05,1.69]$ & $0.80[0.09,1.52]$ \\
\hline DL vs. SL (sport, performance outcomes) & $-0.19[-1.25,0.87]$ & $-0.19[-1.00,0.69]$ & $-0.19[-0.64,0.26]$ \\
\hline DL vs. TL (sport, technical skills) & $0.34[0.12,0.55]$ & $0.37[0.17,0.58]$ & $0.46[0.26,0.66]$ \\
\hline DL vs. TL (sport, tactical behavior) & $0.41[0.03,0.79]$ & $0.43[0.05,0.81]$ & $0.45[0.08,0.83]$ \\
\hline DL vs. TL (fine motor skills) & $-0.11[-0.97,0.74]$ & $-0.12[-1.04,0.79]$ & $-0.13[-1.17,0.90]$ \\
\hline \multirow[t]{2}{*}{ Learning effect } & \multicolumn{3}{|c|}{ pre-retention correlation } \\
\hline & $r=0.15$ & $r=\mathbf{0 . 5 0}$ & $r=0.85$ \\
\hline DL vs. TL (sport, performance outcomes) & $2.46[-2.12,7.03]$ & $2.46[-2.12,7.04]$ & $2.46[-2.12,7.04]$ \\
\hline DL vs. SL (sport, performance outcomes) & $-0.18[-1.24,0.88]$ & $-0.18[-0.99,0.63]$ & $-0.18[-0.63,0.27]$ \\
\hline DL vs. TL (sport, technical skills) & $0.52[0.14,0.90]$ & $0.51[0.22,0.81]$ & $0.58[0.28,0.89]$ \\
\hline DL vs. TL (fine motor skills) & $1.13[0.73,1.54]$ & $1.14[0.73,1.51]$ & $1.16[0.73,1.60]$ \\
\hline
\end{tabular}

3.2.3. Publication bias. Figure 4 presents the funnel plot of all included studies. Visually, a moderate asymmetry towards the right is present in both funnel plots, but this is primarly due to the presence of strong outliers in both directions (Beckmann \& Shöllhorn, 2006; James \& Conatser, 2014; Schöllhorn et al., 2006). However, not every study could be included in the meta-analysis, which biases the interpretation of the funnel plots. Additionally, we are aware of many studies on DL that are available only as conference abstract ${ }^{1}$, so publication bias is very likely. This bias may indicate that the true overall effect sizes are lower.
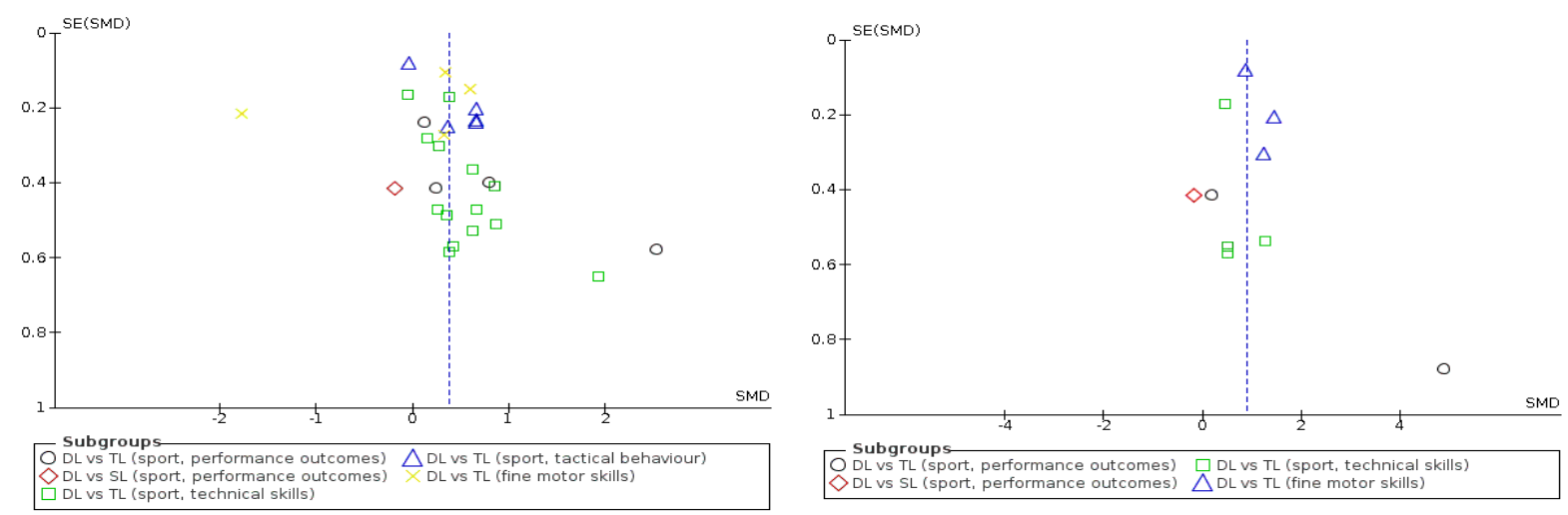

Figure 4: Funnel plots of the effect sizes of the acquisition (left) and retention (right) meta-analyses. Vertical dashed line shows the overall effect size.

1 https://sport.uni-mainz.de/publikationsliste/. In: University of Mainz website. 
3.2.4. Limitations of the studies and of the review/meta-analysis. Given the nature of the motor learning experiments, subjects and trainers/therapists cannot be blinded as to which condition they are in. Therefore, more effort should be made in future studies to take the other risk of bias items into account during planning or provide a more accurate description of them. For both the acquisition and learning effect, the study with the lowest risk of bias (Pabel et al., 2018) was in line with the subgroup and omnibus effect size estimate. Publication bias and the exclusion of certain experiments from the meta-analysis may have influenced the results. The meta-analysis was based on a very heterogeneous sample of studies concerning populations and tasks. For the acquisition phase, the subgroups based on type of task and type of control condition was not a significant factor in explaining the heterogeneity, however, only 1 study compared DL to SL (Hossner et al., 2016b), all other compared it to TL (future analyses may consider further subgroups for REP and MSE comparisons). Regarding heterogeneity in sample charactristics, future analyses may additionally consider subgroup analyses based on age and/or level of expertise as we grouped results from complete novices and experts in the same analysis. A final limitation is the unknown pre-post and pre-retention correlations in the study reports. The sensitivity analysis showed that this parameter had only a small influence on the overall effect sizes and their $95 \% \mathrm{CI}$, but this assumed a fixed correlation coefficient across all studies and may potentially have a larger influence. The overview of effect sizes and their 95\% CI may be used in the planning of future interventions.

These limitations prevent the generalization of the results. The evidence base for the comparison of DL vs TL is relatively large but contains publication bias and many studies with high/unclear risk of bias. For the comparison of DL to other motor learning approaches inspired by variability (VP, CI, CLA, SL), too few evidence exists to examine whether DL can be an advantage in terms of learning rate/performance. 


\section{Discussion and conclusion}

Differential learning is a motor learning method based on large amounts of variability during practice. The differences with other approaches that employ practice variability are the amount and/or structure of the exercise variations or stochastic perturbations. The inverted Ushape model of Schöllhorn, Mayer-Kress, et al. (2009) depict various approaches in a continuum of increasing variability (REP, MSE, VP, CI, CLA, SL, DL) with DL exemplifying the highest learning rates ('stochastic resonance'). The problem with this model is twofold: (1) the model cannot be falsified without a quantification of the amount and structure of practice variability and hence, no experiment thus far has tested this model. (2) the model is incomplete according to other assumptions of the DL proponents - individuality and dynamic conditions of the perceptual-motor learner. The model should depict a time-depending inverted U-shape whereby the location may shift according to as-of-yet unknown factors. In a recent review, Caballero et al. (2017) concluded that various characteristics of task and individual are likely to contribute to the effect of variability, but that experimental manipulation of variability according to these characteristics remains a poorly explored area. Given the rationale behind DL, one of the primary tasks for future studies will therefore be to identify these factors (e.g. age, skill level, motivation, etc.). Knowledge of these factors would allow individualized selection of the amount of practice variability.

In line with Beek (2011), we are inclined to say that DL is a promising method and that the rationale behind it is sound, but too metaphorical instead of operationally defined and that much further research is necessary with more qualitative RCTs and publication in peerreviewed journals in the academic lingua franca. The list of features that DL promises (see introduction) is overly optimistic at some points (most effective learning) and out of the blue without any evidence at other points (changing personality, preventing injuries). We hope that 
with this review, the next 20 years of studies on DL will provide answers to some of the issues raised here. 


\section{References}

Barbado, M., Caballero, S., Moreside, J., Vera-Garcia, F. J., \& Moreno, F. J. (2017). Can the structure of motor variability predict learning rate? Journal of Experimental Psychology. Human Perception and Performance, 43(3), 596-607. https://doi.org/10.1037/xhp0000303

Beckmann, H., \& Shöllhorn, W. I. (2006). Differenzielles Lernen im KugelstoBen. Leistungssport, 1(2), 44-50.

Beckmann, H., Winkel, C., \& Schöllhorn, W. I. (2010). Optimal range of variation in hockey technique training. International Journal of Sport Psychology, 41(4 SUPPL.), 5-10.

Beek, P. J. (2011). Nieuwe, praktisch relevante inzichten in techniektraining Motorisch leren: het belang van random variaties in de uitvoering (deel 5). Sportgericht, 65(6), 30-35.

Bernstein, N. A. (1967). The co-ordination and regulation of movements. Oxford: Pergamon Press.

Borenstein, M., Hedges, L. V., Higgins, J. P. T., \& Rothstein, H. R. (2009). Introduction to Meta-Analysis. West Sussex: Wiley.

Bozkurt, S. (2018). The effects of differential learning and traditional learning trainings on technical development of football players. Journal of Education and Training Studies, 6(4), 25-29. https://doi.org/10.11114/jets.v6i4a.3229

Brady, F. (2004). Contextual Interference: a Meta-Analytic Study. Perceptual and Motor Skills, 99(4), 116-126. https://doi.org/10.2466/PMS.99.4.116-126

Button, C., Lee, C.-Y. M., Mazumder, A. D., Tan, W. K. C., \& Chow, J.-Y. (2012). Empirical Investigations of Nonlinear Motor Learning. The Open Sports Sciences Journal, 5(Suppl 1-M6), 49-58.

Caballero, C., Moreno, F., Reina, R., Roldán, A., Coves García, A., \& Barbado, D. (2017). The role of motor variability in motor control and learning depends on the nature of the task and the individual's capabilities. European Journal of Human Movement, 38, 12 26.

Coutinho, D., Santos, S., Gonc, B., Travassos, B., Wong, P., Schöllhorn, W., \& Sampaio, J. (2018). The effects of an enrichment training program for youth football attackers. Plos One, 13(6). https://doi.org/10.1371/journal.pone.0199008

Davids, K., Araújo, D., Shuttleworth, R., \& Button, C. (2003). Acquiring Skill in Sport: A Constraints-Led Perspective. International Journal of Computer Science in Sport, 2(2), 31-39.

Dhawale, A. K., Smith, M. A., \& Ölveczky, B. P. (2017). The Role of Variability in Motor Learning. Annual Review of Neuroscience, 40, 479-498. https://doi.org/10.1146/annurev-neuro-072116-031548 
Frank, T. D., Michelbrink, M., Beckmann, H., \& Schöllhorn, W. I. (2008). A quantitative dynamical systems approach to differential learning: Self-organization principle and order parameter equations. Biological Cybernetics, 98(1), 19-31. https://doi.org/10.1007/s00422-007-0193-x

Gokeler, A., Neuhaus, D., Benjaminse, A., Grooms, D. R., \& Baumeister, J. (2019). Principles of Motor Learning to Support Neuroplasticity After ACL Injury: Implications for Optimizing Performance and Reducing Risk of Second ACL Injury. Sports Medicine. https://doi.org/10.1007/s40279-019-01058-0

Hatze, H. (1986). Motion variability-its definition, quantification, and origin. Journal of Motor Behavior, 18(1), 5-16. https://doi.org/10.1080/00222895.1986.10735368

Henz, D., John, A., Merz, C., \& Schöllhorn, W. I. (2018). Post-task Effects on EEG Brain Activity Differ for Various Differential Learning and Contextual Interference Protocols. Frontiers in Human Neuroscience, 12(January), 1-10. https://doi.org/10.3389/fnhum.2018.00019

Henz, D., \& Schöllhorn, W. I. (2016). Differential Training Facilitates Early Consolidation in Motor Learning. Frontiers in Behavioral Neuroscience, 10(October), 1-9. https://doi.org/10.3389/fnbeh.2016.00199

Hossner, E. J., Käch, B., \& Enz, J. (2016a). On experimental designs, differencial learning, theoretical issues, dynamical systems, and the capability to adapt: Response to Schöllhorn. Human Movement Science, 47, 246-249. https://doi.org/10.1016/j.humov.2015.11.019

Hossner, E. J., Käch, B., \& Enz, J. (2016b). On the optimal degree of fluctuations in practice for motor learning. Human Movement Science, 47, 231-239. https://doi.org/10.1016/j.humov.2015.06.007

James, E. G. (2014). Short-term differential training decreases postural sway. Gait and Posture, 39(1), 172-176. https://doi.org/10.1016/j.gaitpost.2013.06.020

James, E. G., \& Conatser, P. (2014). Effects of practice variability on unimanual arm rotation. Journal of Motor Behavior, 46(4), 203-210. https://doi.org/10.1080/00222895.2014.881314

Kelso, J. A. S. (1995). Dynamic Patterns. The self-organization of brain and behaviour. Cambridge, MA: MIT Press.

Künzell, S., \& Hossner, E. J. (2012). Differenzielles Lehren und Lernen: Eine Kritik. Sportwissenschaft, 42(2), 83-95. https://doi.org/10.1007/s12662-012-0251-y

Künzell, S., \& Hossner, E. J. (2013). Differenzielles Lehren und Lernen: Eine Erwiderung. Sportwissenschaft, 43(1), 61-62. https://doi.org/10.1007/s12662-013-0287-7

Lage, G. M., Ugrinowitsch, H., Apolinário-Souza, T., Vieira, M. M., Albuquerque, M. R., \& Benda, R. N. (2015). Repetition and variation in motor practice: A review of neural 
correlates. Neuroscience and Biobehavioral Reviews, 57, 132-141.

https://doi.org/10.1016/j.neubiorev.2015.08.012

Mateus, N., Santos, S., Vaz, L., Gomes, I., \& Leite, N. (2015). The effect of a physical literacy and differential learning program in motor, technical and tactical basketball skills. Revista de Psicologia Del Deporte, 24(3), 73-76.

Moher, D., Liberati, A., Tetzlaff, J., \& Altman, D. G. (2009). Preferred reporting items for systematic reviews and meta-analyses: the PRISMA statement. PLoS Medicine, 6(7), 16. https://doi.org/10.1371/journal.pmed.1000097

Morris, S. B. (2008). Estimating effect sizes from pretest-posttest-control group designs. Organizational Research Methods, 11(2), 364-386.

https://doi.org/10.1177/1094428106291059

Orth, D., van der Kamp, G. J. P., Memmert, D., \& Savelsbergh, G. J. P. (2017). Creative motor actions as emerging from movement variability. Frontiers in Psychology, 8. https://doi.org/10.3389/fpsyg.2017.01903

Pabel, S.-O., Freitag, F., Hrasky, V., Zapf, A., \& Wiegand, A. (2018). Randomised controlled trial on differential learning of toothbrushing in 6- to 9-year-old children. Clinical Oral Investigations. https://doi.org/10.1007/s00784-017-2313-x

Pabel, S.-O., Pabel, A.-K., Schmickler, J., Schulz, X., \& Wiegand, A. (2017). Impact of a Differential Learning Approach on Practical Exam Performance: A Controlled Study in a 1108 Preclinical Dental Course. Journal of Dental Education, 81(9), 1108-1113. https://doi.org/10.21815/JDE.017.066

Ranganathan, R., \& Newell, K. M. (2013). Changing up the routine: intervention-induced variability in motor learning. Exercise and Sport Sciences Reviews, 41(1), 64-70. https://doi.org/10.1097/JES.0b013e318259beb5

Renshaw, I., Chow, J. Y., Davids, K., \& Button, C. (2015). Nonlinear Pedagogy in Skill Acquisition. An Introduction. London: Routledge.

Repšaitè, V., Vainoras, A., Berškienė, K., Baltaduonienė, D., Daunoravičienė, A., \& Sendžikaite, E. (2015). The effect of differential training-based occupational therapy on hand and arm function in patients after stroke: Results of the pilot study. Neurologia I Neurochirurgia Polska, 49(3), 150-155. https://doi.org/10.1016/j.pjnns.2015.04.001

Reynoso, S. R., Solana, R. S., Vaillo, R. R., \& Hernandez, F. J. M. (2013). Aprendizaje diferencial aplicado al saque de voleibol en deportistas noveles. Apunts Educación Física y Deportes, 114(4), 45-52. https://doi.org/10.5672/apunts.2014-0983.es. (2013/4).114.04

Santos, S., Coutinho, D., Gonçalves, B., Schöllhorn, W., Sampaio, J., \& Leite, N. (2018). Differential Learning as a Key Training Approach to Improve Creative and Tactical Behavior in Soccer. Research Quarterly for Exercise and Sport, 00(00), 1-14. https://doi.org/10.1080/02701367.2017.1412063 
Savelsbergh, G. J. P., Kamper, W. J., Rabius, J., De Koning, J. J., \& Schöllhorn, W. I. (2010). A new method to learn to start in speed skating: A differencial learning approach. International Journal of Sport Psychology, 41, 415-427.

Schmidt, R. A. (1975). A Schema Theory of Discrete Motor Skill Learning. Psychological Review, 82(4), 225-260. https://doi.org/10.1037/h0076770

Schöllhorn, W. I. (1999). Individualität - ein vernachlässigter Parameter? Leistungssport, (2), $7-12$.

Schöllhorn, W. I. (2000). Applications of systems dynamic principles to technique and strenght training. Acta Academiae Olympiquae Estoniae, 8, 67-85.

Schöllhorn, W. I. (2016). Invited commentary: Differential learning is different from contextual interference learning. Human Movement Science, 47, 240-245. https://doi.org/10.1016/j.humov.2015.11.018

Schöllhorn, W. I., Beckmann, H., \& Davids, K. (2010). Exploiting system fluctuations. Differential training in physical prevention and rehabilitation programs for health and exercise. Medicina Kaunas, 46(6), 365-373.

Schöllhorn, W. I., Beckmann, H., Janssen, D., \& Drepper, J. (2010). Stochastic perturbations in athletics field events enhance skill acquisition. In I. Renshaw, K. Davids, \& G. J. P. Savelsbergh (Eds.), Motor Learning in Practice: A Constraints-Led Approach (pp. 6982). London: Routledge. https://doi.org/10.4324/9780203888100

Schöllhorn, W. I., Beckmann, H., Michelbrink, M., Sechelmann, M., Trockel, M., \& Davids, K. (2006). Does noise provide a basis for the unification of motor learning theories? International Journal of Sport Psychology, 37, 1-21.

Schöllhorn, W. I., Hegen, P., \& Davids, K. (2012). The Nonlinear Nature of Learning - A Differential Learning Approach. The Open Sports Sciences Journal, 5(Suppl 1-M11), 100-112. https://doi.org/10.2174/1875399X01205010100

Schöllhorn, W. I., Humpert, V., Oelenberg, M., Michelbrink, M., \& Beckmann, H. (2008). Differenzielles und Mentales Training im Tennis. Leistungssport, (6), 10-14.

Schöllhorn, W. I., Mayer-Kress, G., Newell, K. M., \& Michelbrink, M. (2009). Time scales of adaptive behavior and motor learning in the presence of stochastic perturbations. Human Movement Science, 28, 319-333. https://doi.org/10.1016/j.humov.2008.10.005

Schöllhorn, W. I., Michelbrink, M., Welminsiki, D., \& Davids, K. (2009). Increasing stochastic perturbations enhances acquisition and learning of complex sport movements. In D. Araujo, H. Ripoll, \& M. Raab (Eds.), Perspectives on Cognition and Action in Sport (pp. 59-73). Berlin: Nova Science Publishers, Inc. Retrieved from http://eprints.qut.edu.au/28522/ 
Schollhorn, W. I., Sechelmann, M., Trockel, M., \& Westers, R. (2004). Nie das Richtige trainieren, um richtig zu spielen. Leistungssport, 5(December), 13-17. Retrieved from papers2://publication/uuid/B58322CD-2626-40F8-A889-6A5B6C4FF572

Schultz, W., Dayan, P., \& Montague, R. R. (1997). A neural substrate of prediction and reward. Science, 275, 1593-1599.

Shamseer, L., Moher, D., Clarke, M., Ghersi, D., Liberati, A., Petticrew, M., ... Whitlock, E. (2015). Preferred reporting items for systematic review and meta-analysis protocols (prisma-p) 2015: Elaboration and explanation. BMJ, 349(g7647). https://doi.org/10.1136/bmj.g7647

Turvey, M. T. (1990). Coordination. American Psychologist, 45, 938-953. Retrieved from http://psycnet.apa.org/journals/amp/45/8/938/\%5Cnhttp://www2.lib.purdue.edu:5733/sp a/ovidweb.cgi? $\& S=I N J G F P J A N F D D F A B K M C F L O B N K M K I E A A 00 \& L i n k+$ Set=S.sh.15.16.19.40

Valentiner, P. (2007). https://www.youtube.com/watch?v=U2AMfyyUt5c\&t=12s.

Weisner, K., Knittel, M., Jaitner, T., \& Deuse, J. (2018). Advances in Human Factors in Training, Education, and Learning Sciences. In S. Nazir, A. M. Teperi, \& A. PolakSopińska (Eds.), Advances in Human Factors in Training, Education, and Learning Sciences (Vol. 596). Berlin: Springer. https://doi.org/10.1007/978-3-319-60018-5

Wu, H. G., Miyamoto, Y. R., Castro, L. N. G., Ölveczky, B. P., \& Smith, M. A. (2014). Temporal structure of motor variability is dynamically regulated and predicts motor learning ability. Nature Neuroscience, 17(2), 312-321. https://doi.org/10.1038/nn.3616.Temporal

Wulf, G., \& Lewthwaite, R. (2016). Optimizing performance through intrinsic motivation and attention for learning: The OPTIMAL theory of motor learning. Psychonomic Bulletin \& Review. https://doi.org/10.3758/s13423-015-0999-9

Zanone, P. G., \& Kelso, J. A. S. (1992). Evolution of Behavioral Attractors With Learning: Nonequilibrium Phase Transitions. Journal of Experimental Psychology: Human Perception and Performance, 18(2), 403-421. https://doi.org/10.1037/0096-1523.18.2.403 